Western Kentucky University

From the SelectedWorks of Eric Kondratieff

Fall 2009

\title{
Reading Rome's Evolving Civic Landscape in Context: Tribunes of the Plebs and the Praetor's Tribunal
}

Eric Kondratieff, Western Kentucky University 


\title{
READING ROME'S EVOLVING CIVIC LANDSCAPE IN CONTEXT: TRIBUNES OF THE PLEBS AND THE PRAETOR'S TRIBUNAL
}

\author{
ERIC J. KondratiefF
}

\section{$\mathrm{T}$}

HE FOLLOWING DISCUSSION HAD ITS GENESIS in my research on tribunes of the plebs in the last two centuries of the Roman republic, including the impact that their activity had on the development of Rome's civic topography and that Rome's changing urban landscape had on tribunician activity. One example of this dynamic process involves the transfer of the tribunal of the praetor urbanus from the edge of the Comitium, where it had stood for nearly three centuries, to the Forum's eastern end. What the praetor's tribunal had to do with the tribunes, why its removal may have been caused by their activities, when it was moved, and the functional and symbolic impact this change may have had on praetors and tribunes alike - all situated within the framework of contemporary historical developments - are the subjects at hand. To discuss all of this properly, I must begin with Sulla.

As dictator in 82 and 81 , Sulla carried through a mass of administrative and constitutional reforms to establish the Roman state on a firmer footing, among which were his enhancement of the Senate's authority and expansion of its membership to 600 . Not content with reshaping Rome's legal and political scene, Sulla also undertook to leave his mark on the city's urban landscape with numerous building projects. To accommodate his newly enlarged senate, he had the Curia Hostilia demolished and rebuilt on a grander scale. ${ }^{1}$ Beyond its practical purpose, the new curia stood as a powerful symbol of the Senate's prestige and dominance in Sulla's new regime, reinforced by a gilt equestrian statue of Sulla himself on the nearby Rostra. ${ }^{2}$ But that is not all. According to some modern

${ }^{1}$ This paper has seen multiple revisions since the original was given at a University of Pennsylvania colloquium in 2003, including versions for the American Philological Association (Jan. 2005), the University of California, Berkeley (Mar. 2005), and a conference on "Spaces of Justice in the Roman World" at Columbia University (Nov. 2007). It has benefited greatly in the details thanks to the critiques of various auditors including T. C. Brennan, B. D. Shaw, J. J. McInerney, E. Gruen, W. V. Harris, B. Frier, L. Bablitz, and others; also, the perceptive insights of the anonymous readers for Pboenix and Temple University colleagues D. Tompkins, M. Davis, and L. Samponaro. All remaining errors are my own. All dates are B.C.E. unless otherwise noted.

On the Curia, see Dio 40.50.2-3, 44.5.2. For ancient references on Sulla's reforms in general (first and second consulships and dictatorship): Broughton 1951-86: 2.39-40, 74-76, and 79 . On Sulla and the tribunate in particular, Kunkel and Witman 1995: 655-659, Sandberg 2001: 36-40.

${ }^{2}$ On the equestrian statue, see App. B. Civ. 1.97; Cic. Pbil. 9.13; Vell. Pat. 2.61.3; Polyaenus 8.23.31; Crawford 1974: 381/1a and 381/1b. The statue did not long survive: it was destroyed by members of the populace upon receiving news of Caesar's victory over Pompey at Pharsalus (Suet. Iul. 75.4; Dio 42.18.2; cf. Dio 43.49.1-2 and Plut. Caes. 57.4). 
scholars, the new building also symbolically diminished the tribuni plebis and the tribal assembly by partially covering the Comitium, or assembly area, located in front of the curia. ${ }^{3}$

This interpretation seems to have arisen from a combination of factors. One is an understanding of the site's topography based on ancient testimonia: Pliny notes that statues of Pythagoras and Alcibiades stood in the corners of the Comitium until Sulla built his curia on the site; ${ }^{4}$ Asconius observes that the old Rostra stood "near the Comitium almost beside [Sulla's] curia." ${ }^{5}$ Both statements could be taken to indicate that the new curia seriously encroached on the assembly area, as could Cicero's remark that it "closely watches and guards over the Rostra as the punisher of folly and director of duty. ${ }^{n 6}$ Another factor is Sulla's well-known emasculation of the tribunate through laws aimed at limiting the tribunician veto, ${ }^{7}$ prohibiting tribunes from independently initiating legislation, ${ }^{8}$ and barring extribunes from holding subsequent magistracies and from sitting on juries. ${ }^{9}$ Since he crushed the tribunate legally, one might suppose, why should he not have done it symbolically as well? But this is only circumstantial evidence, none of which constitutes proof that Sulla's curia actually covered any part of the Comitium. A more important factor in this theory was a reading of the site's stratigraphy and underlying topography that misconstrued developments of the late first century as Sullan-era changes. Carafa, however, recently demonstrated that although it loomed larger than the old Curia Hostilia, Sulla's new senate house was built in the same location and along virtually the same lines of orientation as the old curia; it actually stood clear of the Comitium, which would not be obliterated-in whole or in part-until Julius Caesar began a complete reconfiguration of public spaces and buildings in the western Forum. ${ }^{10}$

${ }^{3}$ See, for example, Coarelli 1992: 233-237; Richardson 1992: 97-98 s.v. "Comitium”; Murray and Petsas 1989: 117-121.

${ }^{4}$ Plin. NH 34.26: invenio [statuas] et Pythagorae et Alcibiadi in cornibus comitii positas, cum bello Samniti Apollo Pythius iussisset fortissimo Graiae gentis et alteri sapientissimo simulacra celebri loco dicari. Eae stetere, donec Sulla dictator ibi curiam faceret ("I find that statues to Pythagoras and Alcibiades were erected on the corners of the Comitium when during the Samnite War Apollo Pythius had ordered that effigies be dedicated in a conspicuous place to the bravest of the Greek race and, likewise, to the wisest. They remained until Sulla, as dictator, built his Curia there").

${ }^{5}$ Asc. 42C: Erant enim tunc rostra non eo loco quo nunc sunt sed ad comitium, prope iuncta curiae ("For the Rostra was not in the same place where it is now, but near the Comitium, almost beside [or, nearly connected to] the Curia"); Coarelli 1992: 240-242 and n. 32 discussing this passage.

${ }^{6}$ Cic. Flac. 57 (in 59 в.c.): cum speculatur atque obsidet rostra vindex temeritatis et moderatrix offici curia. The elite audience, an extortion-court jury, consisted of twenty-five senators, twenty-five knights, and twenty-five tribuni aerarii, the latter classed by Cicero among the Equestrians (Cic. Flac. 4).

${ }^{7}$ Cic. Leg. 3.9.22, Verr. 2.1.155; Caes. BC 1.5, 7; Suet. Iul. 5.

${ }^{8}$ Liv. Per. 89; cf. App. B. Civ. 1.60.

${ }^{9}$ Cic. Verr. 1.30, Cluent. 148.

${ }^{10}$ Carafa 1998: 151-155; Morstein-Marx 2004: 48, 56. For Caesar's reorientation of the Curia and relocation of the Rostra, see Carafa 1998: 156-159; for the older theory, see, for example, Favro 1996: 60-78; Coarelli: 1992: 233-57; Murray and Petsas 1989: 117-121. 
In light of this new evidence, the theory that Sulla's reconstruction of the senate house was intended to symbolically oppress the people and their tribunes appears to be overstated (despite Cicero's stern characterization of the building). ${ }^{11}$ Apparently Sulla had a fairly conservative attitude towards venerable, history-laden loci of political activity, one that correlates well with his political conservatism and his ostensible mission to restore Roman political life back to its pristine, pre-Gracchan form (as he imagined it). It now seems preferable, therefore, to view Sulla's curia as simply a practical and conservative solution to the twin problems of housing, and promoting the public image of, the newly enlarged senate.

This reinterpretation of the evidence for Sulla's building project encourages a reexamination of another, nearly contemporaneous, alteration to the Forum's civic landscape that also has been interpreted as demeaning the tribunes and their role in public affairs: in this case, the transfer of the tribunal of the praetor urbanus from its traditional location at the edge of the Comitium, to the Forum's eastern end in 75 or 74 . The removal of this tribunal from the area most closely associated with tribunician activity -including the Rostra, Comitium and tribunes' offices in the adjacent Basilica Porcia - has been interpreted as physically isolating the tribunes from the machinery of government, and symbolically demonstrating that they were increasingly irrelevant to the senate and imperium-wielding magistrates. ${ }^{12}$ Given Sulla's efforts to diminish tribunician influence and augment senatorial dominance in Roman politics, and given the view that his new curia symbolically crushed the people and their tribunes, this interpretation seemed reasonable enough when offered, and found acceptance among some scholars. ${ }^{13}$ Additional

${ }^{11}$ Morstein-Marx (2004: 56 and n. 78) argues that Sulla's curia aroused feelings of revulsion in the people on the grounds that they chose to burn Clodius in it. But the passage cited indicates that the master arsonist was actually Sextus Clodius, a clerk present at the contio held by tribunes T. Munatius Plancus and Q. Pompeius Rufus in which Clodius' corpse was displayed to the crowd: 'The populus, incited by Sextus Clodius, a clerk, carried Publius Clodius' body into the curia and cremated it using for fuel tribunes' benches, tribunals [i.e., the seating platforms], tables, and notebooks belonging to the clerks; the curia itself caught fire from the blaze, and the Basilica Porcia, which was next door, was also scorched" (Asc. 33C: Populus duce Sex. Clodio scriba corpus P. Clodi in curiam intulit cremavitque subselliis et tribunalibus et mensis et codicibus librariorum; quo igne et ipsa quoque curia flagravit, et item Porcia basilica quae erat ei iuncta ambusta est). The people do not seem to have come to the contio for the purpose of destroying the curia; one might as well argue that they hated the tribunes and scribes whose paraphernalia they used to fuel the fire. Given the political context-Plancus and Rufus' support of Milo's enemies (qui competitoribus Milonis studebant: Asc. 33C)-along with the mob's subsequent attack on the houses of Milo and interrex $\mathrm{M}$. Lepidus, we ought rather to conclude that all this activity was directed at Milo and his supporters, who would have sat in council within the curia, not at the curia itself.

${ }^{12}$ Thommen 1995: 361. His theory builds on his previous work (Thommen 1989), a study of the tribunate in the late republic wherein he argues for the tribunate's continuous decline in the $70 \mathrm{~s}, 60 \mathrm{~s}$, and $50 \mathrm{~s}$.

${ }^{13}$ Millar (1998: 39, n. 69) acknowledges but does not challenge this theory, Mouritsen (2001: 18, n. 1) apparently accepts it. Morstein-Marx (2004: 100, n. 145) also notes the removal of the urban 
support for it could be drawn from the hostility of the nobiles to the lex Aurelia of 75 , which restored to the tribunes the right to pursue further office. ${ }^{14}$ The two changes together could thus be viewed as producing a zero-sum result, with the lex Aurelia's restoration of dignitas to the tribunate nullified by the subsequent physical and symbolic isolation of the tribunes themselves.

A different, more practical interpretation suggests itself, however, when these two changes are considered in a broader context that takes into account not only the politics of the day, but also a diachronic view of the activities associated with the Rostra and the Praetor's Tribunal. ${ }^{15}$ The purpose of this paper, therefore, is to present the relevant evidence for the physical and functional relationship between these two sites and their associated activities, and to demonstrate how it fits more plausibly with what is known of the history, politics, and political culture of the late republic. To do so, we must first situate the tribunes and praetors within Rome's civic landscape prior to 75 .

\section{SITUATING THE TRIBUNES}

Throughout most of the republican era, the tribunes of the plebs maintained a permanent location in the Forum Romanum at the southwestern corner of the Curia Hostilia, the meeting hall in which the senate typically convened to take council. ${ }^{16}$ The tribunes' "offices" also overlooked the Comitium, the square assembly area fronting the Curia where the people gathered to listen to their magistrates or tribunes speak and to vote on legislation relating to domestic issues,

praetor's tribunal to the east end of the Forum in the late republic, but only to comment on the fact that the "civil procedure in iudicio was still located in the Comitium" as seen in Hor. Sat. 1.6.120-121.

${ }^{14}$ Asc. 66-67C: Neque apud Sallustium neque apud Livium neque apud Fenestellam ullius alterius latae ab eo legis est mentio praeter eam quam in consulatu tulit invita nobilitate magno populi studio, ut eis qui tr. pl. fuissent alios quoque magistratus capere liceret; quod lex <a> dictatore L. Sulla paucis annis ante lata probibebat ("There is no mention in Sallust, Livy, or Fenestella of any other law carried by him [Cotta] beyond the one that he carried in his consulship-despite an unwilling nobility-amid great enthusiasm of the people, which provided that those who had been tribunes of the plebs should be allowed to hold additional offices, a step prohibited at the time by a law passed a few years earlier by dictator L. Sulla"). See more fully: Cic. Corn. frs. 18, 51 = Asc. 66-67, 78C; also, Sall. Hist. 2.49, 3.48.8M (Oratio Macri) and ps.-Asc. 255 Stangl.

${ }^{15}$ See Kondratieff 2003: 124-226 for a broad, in-depth discussion of how tribunes functioned in Rome's public spaces and impacted those and other locales through: legislating the building or repairing of structures; consecrating and destroying property of the condemned; and altering or desecrating buildings used in their legislative activities.

${ }^{16}$ The senate also met in other locations, notably the Temple of Jupiter on the Capitol, the Temple of Castor and Pollux in the southeastern Forum, the Temple of Concordia below the Capitol in the western end of the Forum, and the Temple of Bellona adjacent to the Circus Flaminius outside the pomocrium (which afforded promagistrates the opportunity to participate without losing their imperium). None of these locations precluded tribunes from attending. For tribunes attending extra-pomoerial senate meetings in, for example, the Temple of Bellona in the Circus Flaminius, see Liv. 33.22.1-2 (C. Atinius Labeo and C. Afranius, both tr. pl. 196); Liv. 36.39.5-6 (P. Sempronius Blaesus, tr. pl. 191); and Liv. 38.47.1-3 (anonymous tribunes of 187). 
among other things. ${ }^{17}$ From at least the mid-fourth century, the entire Forum began to undergo a series of dramatic physical changes that can be linked to important shifts in Roman politics following the defeat of the Latin League in 338 , and to the concurrent rise of the patricio-plebeian nobility. ${ }^{18}$ Competing with each other for the highest offices, the members of this newly expanded ruling class directed their resources towards building and rebuilding, embellishing and elaborating important locations in the Forum in order to gain popularity among, and votes from, the masses. ${ }^{19}$ Two of the first sites to receive attention in this era of new development were the Comitium and the suggestum, the raised platform next to the Comitium from which orators, most often tribunes, addressed the people. At this time, the suggestum was decorated with the ship's beaks (rostra) from which it acquired its appellation "Rostra"; at the same time, both the Rostra and Comitium began to be decorated with honorific statues of important persons, historical and mythical. ${ }^{20}$

In the early days of the republic, the tribunes sat upon their subsellia (low wooden benches) just outside the Curia's doors so that they could monitor senate debates within. ${ }^{21}$ By the end of the third century, they could be found within the senate house itself (even if some or all of them were not yet senators), listening to

${ }^{17}$ Krause 1976: 61, 66; Pina Polo 1989: 190-96; Vaahtera 1993: 116; Carafa 1998: 150-51; Morstein-Marx 2004: 47-48. For recent work on the locations and competencies of comitia, see Paananen 1993; Sandberg 1993 (and 2001: passim); and Kondratieff 2003: 131-134, 146-154, 183-189.

${ }^{18}$ In 1978, Hölscher (1978: 315-357) cogently argued that Roman official art began ca 338, impelled by important shifts in Roman politics resulting from the new era of expansion following the defeat of the Latin League and the rise of the Roman nobilitas. Several new genres of civic display developed in this milieu, notably the public display of spolia, paintings depicting important geographical locations or historical events, honorific statues, and coinage. See also Pietilä-Castren 1987; Hölkeskamp 1993: 27-29; and Flower 1996: 70-79.

${ }^{19}$ Hölkeskamp (1993: 30) cogently notes that the meritocratic ideology of the nobiles involved selfdefinition and legitimization through "lifelong dedication to the res publica alone" and in reciprocation, the bestowal of various bonores by the populus, "because popular participation was part and parcel of the institutional, social and ideological framework which this élite dominated and defined."

${ }^{20} \mathrm{On}$ the monumentalization of the Comitium and Forum at this time by C. Maenius, cos. 338, and others see, for example, Coarelli 1992: 145-146 and Richardson 1992: 97-98, s.v. "Comitium." More generally, see Ammerman 1990; Coarelli 1992: 11-122 (on the Comitium and adjacent areas), Coarelli 1993b (on the Comitium), and Purcell 1995: 327, relating the changes of 338 to the Licinian-Sextian legislation of 366, a whole generation earlier. More recently Carafa (1998: 143-147) challenged Coarelli, arguing that archaeological evidence is lacking for substantial changes to the Rostra or Comitium in 338. Nevertheless, the monumentalization of this area by C. Maenius did not have to include a major reconstruction project, just the erection of his honorific column and the decoration of existing structures with spoils of war, or monumenta (in the sense of tokens of remembrance). The addition of bronze rams to, or the setting up of bronze statues on, the Rostra would not have required major alterations to this structure, but the change in its visual aspect would have been impressive.

${ }^{21}$ Hug 1932 s.v. subsellium. Cf. Sutherland 1984: 406, a denarius depicting Augustus and Agrippa dressed as tribunes, sitting together on a tribune's bisellium. Also nearby was the Tabula Valeria, a 
debates, promulgating their own relationes and supporting or vetoing the proposals of others. When not in senate meetings, the tribunes normally kept their benches in the traditional location or, after 184, just inside the Basilica Porcia, built by Cato the Censor adjacent to the southwestern corner of the Senate house. ${ }^{22}$ But beyond their need to monitor the senate, to give speeches on the nearby Rostra, or to pass legislation in the adjacent Comitium, the tribunes maintained their "offices" in this location because they also needed to remain in close proximity to a cluster of sites aptly termed the "topography of punishment," where their assistance was frequently required. ${ }^{23}$

The "topography of punishment" included the Carcer located on the lower eastern flank of the Capitoline Hill. This was a small jail with an underground dungeon, the so-called Tullianum, in which malefactors were detained and defeated enemy commanders strangled. ${ }^{24}$ Since the main path to this building passed by the tribunes' benches, those on their way to incarceration could easily request tribunician intercession up to the moment they were thrust into jail. ${ }^{25}$ Farther up the Capitoline, but still within view of the tribunes' benches, was the infamous Tarpeian Rock, from which numerous people-legally condemned for capital crimes, or victims of civil violence - were cast headlong to their deaths on the rocks below. ${ }^{26}$ Since the routes up to the Capitoline began near the tribunes'

third-century painting hung on the western side of the Curia near the tribune's benches, later perhaps just inside the Basilica Porcia (see below, n. 22) which became metonymic for the tribunes' offices (Cic. In Vatin. 21; Fam. 14.2.2; cf. Asc. 91C; Richardson 1992: 376 s.v. "Tabula Valeria"). It is not certain whether the tribunes maintained their "offices" next to the new Curia Julia, completed in 29, with its different orientation.

${ }^{22}$ Cato was well served in the early 180 s by friendly tribunes who helped him pursue his feuds with P. and L. Scipio and T. and L. Quinctius Flamininus (see, e.g., Liv. 38.54.2-4); the location of his Basilica so near to the Curia, thus providing additional convenience to the tribunes, may have been something of a kickback to his helpers.

${ }^{23}$ Purcell 1995: 33 coined this phraseology, which I employ here. See also Kondratieff 2003: 170-176 for a more extended discussion of tribunician activity in this area.

${ }^{24}$ Coarelli 1993a; Richardson 1992: 71 s.v. "Carcer."

${ }^{25}$ See Kondratieff 2003: 526 s.v. "arrests, imprisonments," 527 s.v. "auxilium -imprisonment," and 590 s.v. "topography - Capitol: Carcer / Tullianum" for nearly forty instances of tribunician activity relating to threatened or actual imprisonment in the Carcer from 212 to 44 B.c.E.. Whether people actually received auxilium is another question. Early in the first century, a certain P. Munatius donned a votive crown of flowers that he had removed from the statue of Marsyas, a symbol of Plebeian freedoms, located on the edge of the Comitium near the old tribunal praetoris (Coarelli 1992: 91-119 and Richardson 1992: 370-371 s.v. "Statua Marsyae"). Arrested for sacrilege by the IIlviri capitalis, he appealed to the tribunes as he was being thrust into jail, but they refused to intercede (Plin. NH 21.8). For a dozen other instances from 205 to 55 B.c.e. (eight of giving and four of refusing auxilium to those being or already having been incarcerated), see Kondratieff 2003: 527 s.v. "auxilium-imprisonment."

${ }^{26}$ Richardson 1992: 344 s.v. "Saxum Tarpeium" and 377-378 s.v. "Rupes Tarpeia"; Wiseman 1999. There is some difficulty in establishing the exact location on the Capitoline of the Saxum Tarpeium (outside the Area Capitolina), which Richardson argues is sometimes confused with the 
benches, the tribunes could easily intervene to save lives, if they wished. ${ }^{27}$ Even the Comitium, the assembly area normally used for oratory, legislative activity, and public trials (iudicia populi) ${ }^{28}$ had an important role in the "topography of punishment": here people consigned to corporal punishment, for example army deserters, would be flogged to within an inch of their lives, then sold into slavery. Paradoxically, while tribunician intercession was most easily accessible from this location, such horrific punishments were frequently carried out under the stern gaze of the tribunes themselves, before whom those being punished had been accused before being tried and condemned. ${ }^{29}$

The mere existence of this "topography of punishment" naturally demanded that the tribunes maintain their offices in an easily accessible, central location from which they could intervene in person on behalf of those requesting auxilium, whether by issuing a command or by physically interposing their own bodies between the involved parties. Less dramatic, though certainly more frequent, were appeals against the judgments of the praetor holding court at his nearby tribunal. $^{30}$ As the Forum became the main location for the permanent courtssome instituted by tribunician laws, others by Sulla's edicts- we may suppose that the need for easy access to tribunician auxilium in a location between the praetorian tribunals and the sites of punishment increased. A natural consequence of their intercessory duties was that the tribunes did not have the option to move their "offices" or benches elsewhere, except temporarily.

Rupes Tarpeia (within the Area Capitolina). Wiseman (1999) makes a strong case for accepting Dion. Hal. 7.35.5, 8.78.5 and Dio 58.15.2-3 as accurately locating the Saxum Tarpeium within view of the entire Forum; he also lists known victims thrown from it.

${ }^{27}$ Kondratieff (2003: 591 s.v. "topography - Capitol: Tarpeian Rock") includes nine instances of tribunician activity involving the Tarpeian Rock from 214 to 47 B.C.E.

${ }^{28}$ For tribunes indicting and prosecuting notable malefactors, such as embezzling or incompetent commanders, in iudicia populi, see Kondratieff 2003: 547-548 s.v. "Iudicia Populi," listing over thirty such prosecutions brought by tribunes between 218 and 99 ; see 177-179 on the "Topography of Justice" and tribunician iudicia populi. The first three stages (of four) of any trial need only be held in a suitably large assembly area for the charges to be made and heard. If the penalty was to be a fine, the fourth, pre-comitial contio, or quarta accusatio, could be held within the pomoerium, i.e., in the Comitium; if the charge was capital, thus to be decided by the centuriate assembly, it had to be presided over by a praetor who had the necessary auspices agere cum populo on behalf of the prosecuting tribune(s), and held on the Capitol or (later) in the Campus Martius.

${ }^{29}$ Liv. Per. 55: in 138C. Matienus was accused apud tribunos plebis ("before the tribunes of the plebs") for deserting the army in Spain, condemned to the yoke and prolonged public flogging, then sold into slavery for one sestertius. Many deserters were similarly punished in the Comitium in the same year (Liv. Oxy. Per. 55 and Frontin. Str. 4.1.20).

${ }^{30}$ See Kondratieff 2003: 527 s.v. "auxilium-legal conviction" for three clearly recorded instances of appeals for auxilium against legal convictions, in 76, 63, and 54. The slim record for such appeals is surely due to the interests of Cicero, our main source for this period, from whose forensic speeches all three examples derive, rather than to an unwillingness of the convicted to appeal to the tribunes for auxilium against a praetor's judgments. Such activities were likely so mundane as not to attract notice, except when they could be used against a prominent person in a public prosecution. 


\section{THE TRIBUNAL OF THE PRAETOR URBANUS AND ITS LOCATION(s)}

The tribunal of the praetor urbanus seems originally to have been situated on the edge of the Comitium, not far from the tribune's benches and the Curia. ${ }^{31}$ That it was set up there after the tribunes had established their offices next to the Curia implies that this seat of judgment was intentionally placed within easy reach of the sources of tribunician auxilium. The relationship between these two locations was often reciprocal: down to the first century, tribunes approached the tribunal of the praetor urbanus to bring capital charges against individuals, and to name a day (diem dicere) on which the praetor would assemble the centuriate assembly for a iudicium populi. By the first century, however, tribunes often preferred simply to bring an accused before the praetor rather than follow the more cumbersome format of a iudicium populi. ${ }^{32}$

In 74 we find the praetor urbanus adjudicating at a new location near the southeastern corner of the Forum adjacent to the Gradus Aurelii, or Aurelian Steps. ${ }^{33}$ The Aurelian Steps are thought to have been grandstands based on Cicero's statement that they resembled a theater. ${ }^{34}$ They apparently faced the newly situated tribunal of the praetor urbanus, itself perhaps to be identified with the Tribunal Aurelium, which seems to have been located near the Temple of Castor and Pollux. ${ }^{35}$ The original view that the Gradus were built of stone has

${ }^{31}$ Liv. 27.50 .9 (207 в.c.E.); Varro LL 5.155; Gell. 20.1.11, 20.1.47; Plaut. Poen. 805, Curc. 470. The exact location of the praetor urbanus' tribunal within the area of the Comitium is contested: Platner and Ashby (1929: 540) follow Jordan (1871: 499-500) in placing it "on the Comitium," then in the forum by the mid-second century, Richardson (1992: 401 s.v. "Tribunal Practoris") refrains from guessing, Coarelli (1992: 22-27 and fig. 5) places the tribunal of the praetor urbanus and the praetor inter perigrinos on the northern edge, flanking the Curia on either side, which arrangement, in principle, Brennan (2000: $106-107$ and $289, \mathrm{n} .71$ ) follows. Brennan also notes the temporary removal in 215 of both tribunals to the southeastern gate so that the praetors could be available for senate meetings held in that vicinity. David (1995) examines the different locations of the praetor's tribunal over time, and the changing image of the praetor as determined by the symbolic meaning inherent in each new set of surroundings. See also David 1992: 14-18.

${ }^{32}$ Brennan (2000: 125-126, 130-131, and 370) discusses these interactions, noting on 370 the first-century decline of the iudicium populi and the apparent increase of instances of tribunes bringing an accused before the praetor.

${ }^{33}$ Brennan (2000: 289, n. 71), following Frier (1983: 223, n. 11 and 1985: 59, n. 56), believes that the praetor's tribunal was placed ca 80 near the Puteal Libonis / Scribonianum. For more details, including recent scholarship that more plausibly dates the collocation of tribunal and Puteal to the period after Caesar's death (an interim stage before the praetor was relocated to the Forum Augustum), see below, 333, n. 51.

${ }^{34}$ Cic. Cluent. 93: gradus illi Aurelii ... quasi pro theatro ... aedificati videbantur ("Those Aurelian steps over there ... seemed to have been built .... to serve as a theater" [or auditorium]). Curved grandstand seating was not a novelty in Rome: Plutarch (CG 12.3-4) mentions circular grandstands built for gladiatorial shows in the Forum in 122; $\mathrm{cf}$. Vitr. 5.5 .7 on the multitude of wooden theaters built annually in Rome. On Roman wooden grandstands and their development, see Welch 2007: 30-71, especially 49-71.

${ }^{35}$ Cicero refers to the Tribunal Aurelium four times in speeches given in 57 (Red. pop. 13, Dom. 54, Pis. 11, and Sest. 34), always in the context of Clodius' activities there in 58. The proximity 
fallen out of favor since excavations in the Forum have failed to reveal any remains that can be positively identified with them. ${ }^{36}$ The fact that neither structure is mentioned after Cicero's time may imply their destruction by fire in the 50 s or 40 s, which would support the more recent view that both Gradus and Tribunal were built of wood (as were most tribunals). ${ }^{37}$ Indeed, one theory holds that they were consigned with other tribunals, desks, and benches to Clodius' funeral pyre in the Curia in $52 ;^{38}$ alternatively, the Gradus Aurelii and Tribunal Aurelium could have been broken up along with the other tribunals and benches used as fuel for Caesar's cremation before the Regia, immediately to the north of their proposed location near the Temple of Castor. ${ }^{39}$

There is some difficulty in accurately dating the construction of the Gradus Aurelii, since the identity of the builder is uncertain. The two most likely candidates are C. Aurelius Cotta, consul in 75, and his brother M. Aurelius Cotta, consul in 74. Coarelli suggested that they were erected by C. Cotta in 81 : this was the year to which prosopographers had dated his praetorship; moreover the building of a new location for a praetor's tribunal seemed a more appropriate activity for a praetor than for a consul, and the date coincided nicely with Sulla's

in each speech of references to Clodius' activities at the Tribunal and at the Temple of Castor has led to the modern assumption that the Tribunal Aurelium was located near, if not directly in front of the temple. That Cicero never mentions the Gradus and Tribunal together in the same speech has been taken by many to indicate that they were related structures, of which Cicero needed to mention only one to indicate both; alternatively, his reference to the Tribunal Aurelium indicated the whole court complex of which the Gradus were part. See, for example, Platner and Ashby 1929: 539-540 s.v. "Tribunal Aurelium"; Coarelli 1992: 192; Purcell 1995: 332-333; and Korhonen 1999. Richardson 1992: 181-182 s.v. "Gradus Aurelii," 400-401 s.v. "Tribunal Aurelium" dissents, arguing that the structures were unrelated precisely because Cicero fails to mention them together. Instead, he connects the Gradus Aurelii to Sulla's newly rebuilt Comitium, now known not to have been rebuilt at the time. He also associates the Tribunal Aurelium with a dais built for levies in the Ovile, the voting enclosure in the Campus (which theory Korhonen [1999] ably refutes), though Richardson also admits that the Tribunal Aurelium may have stood near the Temple of Castor.

${ }^{36}$ Platner and Ashby (1929: 539-540 s.v. "Tribunal Aurelium") believed the Gradus were built of stone; Purcell (1995: 332-333), however, believes that they could have been wooden; if not, they were certainly removed by the time Augustus had the Forum repaved, hence the complete lack of archaeological remains (and the elusiveness of any consensus on their actual nature); Coarelli (1992: 198-199) also notes the lack of identifiable remains.

${ }^{37}$ Purcell 1995: 332-333; Korhonen 1999; cf. Welch 2007: 49-71.

${ }^{38}$ Korhonen (1999) locates the Gradus Aurelii near enough to the Curia to have burned along with it in 52. But since the crowd easily could have transported these materials across the hundred or so meters from the eastern portion of the Forum, pace Korhonen, there is no need to assume the Gradus stood near the Curia. For the materials burned in Clodius' pyre, see Asc. 33C (above, 324, n. 11).

${ }^{39}$ Suet. Iul. 84.3: after Caesar's bier was set alight, "the crowd of bystanders immediately threw onto it dry branches and the tribunals with the judgment seats, and whatever else was there as an offering" (confestimque circumstantium turba uirgulta arida et cum subselliis tribunalia, quicquid praeterea ad donum aderat, congessit); cf. Plut. Caes. 68, Ant. 14.3, and Brut. 20.3 for similar descriptions. For

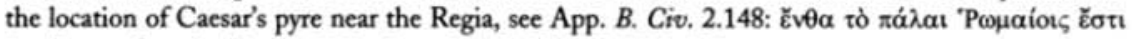

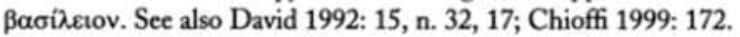


increase of the quaestiones perpetuae. ${ }^{40}$ That $\mathrm{C}$. Cotta must have been praetor no later than 78 is undeniable, since Sulla's legislation on office-holding stipulated that one had to have been praetor before becoming consul, with a minimum of two years between magistracies. ${ }^{41}$ Attempts to date his praetorship to 81 , however, do not stand up under close scrutiny, ${ }^{42}$ and, since he did not hold any games in his praetorship, Cotta was clearly not a praetor urbanus, and so there was no reason for him to have built grandstands to accommodate an audience for performances, much less a large jury for cases held before the urban praetor's tribunal. ${ }^{43}$ Besides, 81 seems too early for the building of the Gradus Aurelii in light of Cicero's testimony in 66 that the structure was brand new when $\mathrm{C}$. Iunius was tried there in 74: "those famous Aurelian steps, new at the time, seemed to have been built as a theater for that court case. ${ }^{n 4}$ Cicero's emphasis on the temporal proximity between construction and court case seems to indicate that the steps were built within months, if not weeks, of Iunius' trial, which brings us back to the consular years of C. and M. Cotta as the most likely date for their construction. ${ }^{45} \mathrm{It}$ seems preferable to suppose that C. Cotta ordered the steps built sometime in 75 , as he

${ }^{40}$ Coarelli 1992: 190-199; Millar (1998: 42-43) follows Coarelli in linking the construction of the Gradus Aurelii to the institution of the quaestiones under Sulla in 81 .

${ }^{41}$ Brennan (2000: 748 and 913, n. 307) dates C. Cotta's praetorship to 78, or just before, for the reasons stipulated in nn. 42-43, below. On Sulla's legislation, see: Cic. Phil. 11.11; App. B Civ. 1.100-101; cf. Cic. Leg. Man. 62, Leg. 3.9, Pbil. 5.47; Caes. BC 1.32; Liv. 7.42.2, 10.13.8.

${ }^{42}$ Coarelli (see above, n. 40) follows Broughton (1951-86: 3.31) in accepting the suggestion of Sumner (1973: 110) that C. Cotta, restored from exile by Sulla (Cic. Brut. 311), was elected praetor in 81 , and that he is the "Cotta" named by Plutarch as commanding pro praetore against Sertorius

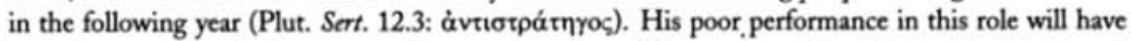
been the reason for the five-year gap between his praetorship and consulship. But the identification of Plutarch's Cotta as C. Cotta was not regarded as certain by Broughton (1951-86: 2.80): "C. ? (or M.?) Aurelius Cotta (96 or 107)." Also, since other commanders received imperium pro praetore without actually having been praetor, even in the Sullan era (e.g., Cn. Pompeius who fought pro praetore in Africa in 80; see Broughton 1951-86: 2.81 for full references), the mere holding of imperium pro praetore in 80 by a Cotta does not prove that he had been praetor before or during 81 , attractive though the idea might be. Konrad (1994: 128-129 s.v. 12.3 Kóttav) argues that Plutarch's usage of

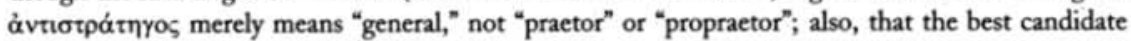
for this "Cotta" would be either L. Cotta, the youngest of the three Cottas, operating as a quaestor attached to Fufidius, then governing Farther Spain; or, even more likely, based on Plutarch's failure to indicate a praenomen, an Aurunculeius Cotta. Brennan (2000: 913, n. 307) rejects a praetorship for C. Cotta in 81 on these and similar grounds.

${ }^{43}$ Cicero (Off. 2.59) lists C. Cotta among those who rose to the highest eminence without ever giving public entertainments. Brennan (2000: 913, n. 307) cites this evidence as proof that C. Cotta had not been praetor urbanus. On 749 he rightly infers a praetorship no later than 77 for M. Cotta based on his consulship in 74; there is no evidence, however, for the type of praetorship he held.

${ }^{44}$ Cic. Cluent. 93: gradus illi Aurelii tum novi quasi pro theatro illi iudicio aedificati videbantur ("Those Aurelian steps over there-new at the time- seemed to have been built to serve as a theater for that trial"); for C. Iunius, a former iudex quaestionis, and his trial, see Cic. Cluent. 1.55, 59, 78, 84, 90-96, 103, 113 and 189, Verr. 1.29, 2.1.157; ps.-Asc. 216, 255-256 Stangl; Schol. Grov. 331, 351 Stangl; Schol. on Pers. Sat. 2.19.

${ }^{45}$ Thus Platner and Ashby 1929: 539-540 s.v. "Tribunal Aurelium"; see also Korhonen 1999. 
was in Rome for the entirety of his consulship, while M. Cotta spent most of his year as consul in Bithynia. ${ }^{46}$ Also favoring $\mathrm{C}$. Cotta is the restoration work in the Forum that may be attributed to his consulship in 75 , when he and his consular colleague let contracts for the inspection and refurbishing of Rome's temples, a job so massive that it had to be delegated (at least in part) to two praetors of 75 and completed by two of the praetors of $74 .^{47}$ In addition, C. Cotta seems to have been responsible for repaving the entire Forum: formerly attributed to Sulla, this project has been down-dated to the years $78-74$ and assigned to an Aurelius Cotta based on Castagnoli's emendation of Fest. 416L. ${ }^{48}$ It does not seem overly speculative to propose that $\mathrm{C}$. Cotta undertook the repaving of the Forum in conjunction with his temple restoration project, perhaps conceived as a single grand work of renovation..$^{49}$ And, as the Temple of Castor was conspicuous among the temples to be inspected and repaired (as deemed necessary) in Cotta's refurbishment project, why not attribute to him the construction of the Gradus Aurelii in its vicinity, perhaps after the Forum's new pavement had been installed? Of course, if the Gradus were indeed constructed of wood, then M. Cotta could easily have seen to their erection early in 74 , as a sort of pendant to his brother's renovations, before departing for his provincial command. ${ }^{50}$ In either case, the

${ }^{46}$ See Broughton 1951-86: 2.96, 100-101 for references.

${ }^{47}$ Cic. Verr. 2.1.130; Brennan 2000: 445-446. The praetors of 75 were M. Caesius and C. Sacerdos; those of 74 were C. Verres and P. Coelius. Verres' supposed abuse of his assignment in relation to the Temple of Castor - "restoration" of the temple in which a few out-of-plumb columns were reset and re-stuccoed-is the subject of Cic. Verr. 2.1.130-157: see Brennan 2000: 445-446 and 819, nn. 23-30. Nielsen (1992: 114), however, comes to Verres' defense, noting that the shoddily constructed Metellan phase of the temple was subject to significant subsidence due to its position atop the "swampy area just east of the Cloaca Maxima." Hence, Verres' "repairs" may have been both called for and sufficient. Frier (1983: 223, n. 11 and 1985: 59, n. 56) assigns to the senate in 80 the letting of contracts for the refurbishment of temples based on Cic. Verr. 2.1.130 in conjunction with Festus $416 \mathrm{~L}$ as emended by Jordan (for which see below, 332, n. 48). While it is clear from the Verrine passage that P. Iunius had been contractor for maintaining the Temple of Castor since Sulla's consulship in 80 , pace Frier, it need not be taken as indicating that a whole series of contracts for temple upkeep had been let by the senate or anyone else in that year.

${ }^{48}$ Coarelli 1992: 196-197; Giuliani (1995) provides a comprehensive summary of the evidence for and theories about the Forum's several pavements; Castagnoli (1964: 192) emends Fest. 416L by replacing the corrupt collostravit with Cotta stravit, as opposed to the emendation Sulla stravit first proposed by Jordan (1871: 525) and accepted by Platner and Ashby (1929: 232, n. 1): Statae matris simulacrum in foro colebatur: postquam id Cotta stravit, ne lapides igne corrumperentur qui plurimis ibi fiebat nocturno tempore, magna pars populi in suos quique v<i cos rettulerunt ei<u>s deae cultum ("An effigy of Stata Mater used to be worshipped in the Forum; after Cotta paved it (the forum), in order that the [new paving] stones would not be spoiled by the fire which used to be lit in many places there during the night, a large part of the populus carried the worship of this goddess to their respective neighborhoods," i.e., lit fires in her honor elsewhere).

${ }^{49}$ Giuliani (1995: 343) favors M. Cotta for this project on the assumption that he was also responsible for the construction of the Tribunal Aurelium.

${ }^{50}$ Platner and Ashby (1929: 539-540 s.v. "Tribunal Aurelium") date the Gradus Aurelii and Tribunal Aurelium to M. Cotta in 74 because Cic. Cluent. 93 (above, 331, n. 42) emphasizes their newness in that year. 
result was a structure named after the consul who undertook its construction, possibly with the purpose of accommodating the newly transferred praetor and his judicial activities.

Why the praetor and his tribunal may have been moved at this time instead of in 81 or 80 is the more difficult question to answer. ${ }^{51}$ If the increase in quaestiones perpetuae and the concomitant increase in the number of praetorian tribunals set up around the Forum-perhaps clustered around the tribunal of the praetor urbanus - had been sufficient reason to precipitate this change, the move should have occurred in 81 or shortly thereafter, not six or seven years later. This long delay eliminates the increase in permanent courts as the immediate cause for the change, although it certainly was a contributing factor. ${ }^{52} \mathrm{~A}$ more pressing reason for the removal of the urban praetor's tribunal - and, perhaps, those of his praetorian colleagues - to the eastern end of the Forum in 75 or 74 may be found

${ }^{51}$ Frier (1983: 223, n. 11 and 1985: 59, n. 56) argues that the praetor's tribunal was placed near the Puteal Libonis / Scribonianum in 80 using the following evidence: the fact that by 74 the praetor urbanus was working in a new location (Cic. Cluent. 93); the "Sullan" repaving of the Forum ca 80 (based on Jordan's reading of Fest. 416L; see above, 332, n. 48), which others date to 78-74 and attribute to a Cotta (also see above, 332, n. 48) or, as here, to C. Cotta in 75; the apparent letting of contracts in 80 by the senate to repair temples (Cic. Verr. 2.1.130; but see, above, 332, n. 47, above, for the difficulty of this interpretation); and the combined testimony of Hor. Ep. 1.19.8 (given here in its full context with 11. 6-11, a sort of mock praetor's edict: Ennius ipse pater numquam nisi potus ad arma prosiluit dicenda. "Forum putealque Libonis mandabo siccis, adimam cantare severis": boc simul edixi, non cessuere poetae nocturno certare mero, putere diurno) and Porph. ad Hor. Ep. 1.19 .8 (illic primum tribunal et subsellia collocata sunt a Libone). Frier postulates that the Libo referred to by Porphryion was an otherwise unknown praetor of the Libo branch of the Scribonii operating in 80 (included by Broughton [1951-86: 3.186-187], but not by Brennan [2000]). Against this and other theories that argue for dating the tribunal's location near the Puteal Libonis earlier than the 40 s B.C.E., Chioffi (1999: 172-173, following Scheid 1975: 362), points out that the first references to the collocation of Tribunal and Puteal are from the late-30s/early-20s or later (Hor. Ep. 1.19.8, Sat. 2.6.34; Porph. ad Hor. Ep. 1.18.9; Ov. Rem. Am. 561; Per. 4.49) and argues that the only Libo notable enough at that time to be known simply by his cognomen (as in Porph. ad Hor. Ep. 1.18.9) would have been L. Scribonius Libo (RE 20), cos. 34, and therefore avers that this Libo probably placed the tribunal near the Puteal Libonis (itself set up by the consul's father or an earlier ancestor, for details of which, see Chioff 1999) perhaps when he was praetor in the late 40s/early 30s (Broughton 1951-86: 2.248, follows Mũnzer in assigning his praetorship to 50 , but warns that he may have been only a legatus in that year, cf. Broughton 1951-86: 3.187; see now Kondratieff forthcoming). The placement of the praetor's tribunal near the puteal between 52 and the early 30 s B.C.E. could thus mark an interim stage between the destruction of the Tribunal Aurelium in 52 or 44 (see above, 330, nn. 38-39) and the transfer of the praetor urbanus to the Forum Augustum several decades later. Indeed, no later than 42 there would have been a real need to find a new space for the praetor's tribunal if it had been located, as proposed here, in or near the area appropriated for the Temple of Divus Julius, then under construction. The exact location of the Puteal Libonis is still unknown: Chioffi (1999) and Noreña (2002) both note the difficulties in pinpointing the wellhead's location, or even the atria before which it was placed (Fest. $448 \mathrm{~L}$ ), because secure archaeological evidence is lacking.

52 Thommen (1995: 361) argues that the removal of this tribunal to the eastern end of Forum in 75 was due to the increase in the number of the quaestiones perpetuae, but does not offer an explanation for the six-year delay. 
in contemporary politics, specifically those events having to do with the tribunes of the plebs and leading up to the lex Aurelia of 75.

\section{TRIBUNES AND THE LEXAURELLA OF 75 B.C.E.}

Sulla's legislative program to render the tribunate virtually impotent was initially quite successful. ${ }^{53}$ Sallust describes it as an "empty shell of a magistracy," Velleius as "shadow without substance. ${ }^{54}$ Appian reports that, because of Sulla's laws, men of reputable or noble family not only ceased to contend for the office, they actually avoided it altogether, for it had become a terminal office, a careerkiller. ${ }^{55}$ That the office continued to be filled is a verifiable fact, but the identities of the men who did fill it, with very few exceptions, were hardly worth recording: men of such low reputation, ability, or ambition that they could not possibly have hoped to win a seat among the tribunes in one of the hard-fought, pre-Sullan campaigns for the tribunate. ${ }^{56}$ Indeed, it would be difficult to argue that the low survival rate of documentation for this period (81-70) is the only reason why we know the names of less than one tribune per year. ${ }^{57}$ Cicero also informs us that, as a result of Sulla's legislation and the subsequent decline in the quality of tribunes, tribunician contiones virtually ceased to be held, a topic to which we shall return shortly..$^{58}$

This situation would not last long, however. Sulla's laws concerning the tribunate came under fire even before his death in 78, and would be a major theme of Rome's domestic politics down to the full restoration of tribunicia potestas by Pompey and Crassus in 70. The (anonymous) tribunes of 78 met with consuls M. Aemilius Lepidus and Q. Lutatius Catulus to request that they overturn Sulla's restrictions on tribunician rights and powers, but they were denied: in a subsequent contio on the topic, likely regarding a proposed bill for the tribunate's restoration, Lepidus persuaded the people that restoring tribunicia potestas would serve no purpose. ${ }^{59}$ His famous reversal of opinion and armed uprising in 77 to bring about, among other things, a full restoration of tribunician powers, also

${ }^{53}$ See above $323, \mathrm{nn} .7-9$.

${ }^{54}$ Sall. Hist. 3.34.3 (Oratio Macri): inani specie magistratus, Vell. Pat. 2.30.4: imago sine re.

${ }^{55}$ App. B. Civ. 1.100.

${ }^{56}$ Kondratieff (2003: 81-88) provides evidence for tribunician elections before Sulla's anti-tribune legislation and after it was rescinded that indicates how fierce competition for the office could be in the later republic, sometimes involving huge bribes, subterfuge, violence and murder. Interestingly, Cicero (Planc. 52) names quite a few men who became praetors or consuls, but who nevertheless failed in their campaigns for a tribunate (Planc. 81-82).

${ }^{57}$ This is not to say we know nothing of their activity. Kondratieff (2003: 436-442) includes thirteen separate notices for "anonymous tribune" activities preserved in ancient sources for the years 81-70.

${ }^{58}$ Cic. Cluent. 110; cf. Asc. 81C; see also above, 325, n. 14.

${ }^{59} \mathrm{Gran}$. Licinian. 33F: verum [ubi] convenerant tribuni plebis consules uti tribuniciam potestatem restituenunt, negavit prior Lepidus, et in contione magna pars adsensast dicenti non esse utile restitui tribuniciam potestatem. et extat oratio. Millar (1998: 58) thinks that a legislative proposal was discussed. 
came to naught. ${ }^{60}$ The next year, tribune $\mathrm{Cn}$. Sicinius spoke boldly for the restoration of the tribunate's powers and status. He even summoned the two consuls to the Rostra, where he hectored them before the people in an attempt to force them to cooperate, but achieved nothing more than his own suppression and death at the hands of one of the consuls whom he had publicly humiliated. ${ }^{61}$

In seventy-five calls for the restoration of tribunician powers continued unabated. ${ }^{62}$ Greater crises, however, now occupied center stage. Abroad, Roman armies fought civil and foreign wars on multiple fronts. At home, Rome's urban plebs were suffering from an intolerable lack of grain and steeply rising prices for their daily bread. Matters finally came to a head when an angry mob started a riot over the grain shortage and violently pursued the consuls down the Via Sacra, where they found refuge in consul L. Octavius' house. ${ }^{63}$ Shortly thereafter-or so the fragments of Sallust's Histories indicate-consul C. Aurelius Cotta gave a conciliatory speech to the plebs, in which he claimed that Rome's dearth of both grain and requisite cash to solve the grain shortage was due to the extensive needs of Roman armies operating in Spain, Asia, Cilicia, and Macedonia, and that the grain crisis had been exacerbated by the reduction of Rome's navy through penury to a skeleton fleet inadequate to safeguard their grain ships from pirates. ${ }^{64}$ Unable to promise to alleviate the shortage, Cotta could only urge the plebs to endure with fortitude the same hardships endured by the armies. Finally, in a rhetorical flourish, he "consecrated" himself on behalf of the state in an oratorical act of devotio. ${ }^{65}$

It is possible that one tribune is actually known: $M^{\prime}$. Acilius $M^{\prime}$. f. M'. n. Glabrio, for whom see Broughton 1951-86: 3.2-3.

${ }^{60}$ Lepidus reversed his position before Sulla's death and after falling out with his co-consul (Sall. Hist. 1.55.1, 16, 24M; App. B. Civ. 1.105), then tried to overthrow Sulla's laws limiting the tribunate and began an armed revolt in 77 , demanding the restoration of tribunician powers and immediate iteration of his consulship (Sall. Hist. 1.55.23, 27M, 1.77.14-15M; Flor. 2.23; App. B. Civ. 1.107; see Broughton 1951-86: 2.85 for further references).

${ }^{61}$ Sall. Hist. 2.23-26M, 3.48.8-10M; ps.-Asc. 189 Stangl; for the "hilarious but coarse wit" that brought about Sicinius' own death at the hands of consul C. Scribonius C. f. Curio, see also Cic. Brut. 216-217; Quint. Inst. Or. 11.3.129; Plut. Crass. 7.9; cf. Millar 1998: 60.

${ }^{62}$ Sall. Hist. 2.45, 49M, 3.48.8M (Oratio Macri) notes assiduous tribunician efforts to retrieve "domination of the plebs" from the senate, surely including Q. Opimius in 75 (see also below, 337, n. 74).

${ }^{63}$ Sall. Hist. 2.45M. The consuls were assisting Q. Metellus (Creticus) in his canvass for a practorship. Cf. Millar 1998: 43-44.

${ }^{64}$ Sall. Hist. 2.47.6-7M. Piracy in the Mediterranean had become intolerable and seemingly ineradicable: Plutarch (Pomp. 24; Caes. 1.8-2.7) provides the best-known descriptions of piracy in the 70s. This eventually precipitated the bestowal of resources and the first special command against pirates upon M. Antonius, father of the triumvir, in 74. Broughton (1951-86: 2.101) suggests Antonius had imperium pro consule. Ps.-Asconius 259 Stangl refers to imperium infinitum: curatio infinita totius orae maritimae, Vell. 2.31, however, refers to imperium aequum up to 50 miles inland of all provinces bordering the sea. See Cic. Verr. 2.2 .8 on Antonius' use of his command to terrorize Sicily; Flor. 1.41 derides Antonius for overconfidence and poor preparation.

${ }^{65}$ Sall. Hist. 2.47.8-14. 
Cotta was fortunate that the grain shortage was temporarily relieved by the intervention of curule aedile $\mathrm{Q}$. Hortensius, who personally underwrote a massive distribution to the plebs of grain at greatly reduced prices. ${ }^{66}$ Nevertheless, Sallust claims that the consul had come to fear the plebs, and therefore attempted to mollify them with a law that removed Sulla's prohibition against tribunes standing for higher offices, thus restoring to the tribunate a measure of status, or dignitas. ${ }^{67}$ Cotta's law, it has been argued, may have served another, more pragmatic purpose: to garner popular support for the consular candidacy of his brother, M. Cotta (cos. 74) ${ }^{68}$ In either case, the law was extremely popular among the populace: Asconius informs us that everyone but the nobiles enthusiastically supported the measure. ${ }^{69}$ Interestingly enough, the anger of the nobiles over the law's passage did not vent itself upon Cotta, who ostensibly passed the law, but upon Q. Opimius, tr. pl. 75 , who greatly assisted the law's passage through his persuasive oratory. ${ }^{70}$ Unfortunately for Opimius, the restoration of dignitas to the tribunate did not confer immunity on former tribunes for their activities while in office: in the year after his tribunate, Opimius was indicted before urban praetor C. Verres for having misused his powers of intercession contrary to the lex Cornelia. This was mere pretext, Cicero tells us, engineered because Opimius had publicly "spoken against the will of some noble. ${ }^{71}$ Cicero perhaps refers to the tribune's contiones in support of the lex Aurelia. In any case, Opimius' utter ruination in Verres' court clearly indicates that nobiles could still find ways to intimidate troublesome tribunes. $^{72}$

Nevertheless, now that the tribunate was no longer a terminal office, ambitious men once again vied to become tribune, and tribunes returned to the Rostra with real frequency. Cicero reports that L. Quinctius, tr. pl., "seized upon the Rostra, now long unoccupied, that place uninhabited by a tribune's voice since Sulla's

${ }^{66}$ Cic. Off. 2.57, Verr. 2.3.215. Curule aedile M. Seius made a similar subsidy in 74: Cic. Off. 2.58 (grain sold at one as per modium), Plin. NH 15.2 (oil sold at one as per $10 \mathrm{lbs}$ ); cf. Millar 1998: 60-61. The grain shortage was not fully addressed until 73, when the so-called lex Terentia et Cassia Frumentaria was passed: Cic. Verr. 5.21.52, cf. 3.70.163; Sall. Hist. 3.48.19M (Oratio Macri).

${ }^{67}$ Cic. Corn. frr. $18,51=$ Asc. $66-67,78 \mathrm{C}$, quoted above, 323, n. 3; Sall. Hist. $2.49,3.48 .8 \mathrm{M}$ (Oratio Macri), notes that Cotta made this concession due to his fear of the plebs; this follows closely on the heels of Sallust's account of the grain riot in Hist. 2.45M.

${ }^{68}$ Seager (1994: 211) argues that Cotta's law was meant to curry favor for his brother's candidacy.

${ }^{69}$ Cic. Corn. frr. 18, 51 = Asc. 66-67: ... [lex] quam in consulatu tulit invita nobilitate magno populi studio; Asc. $78 \mathrm{C}$.

${ }^{70} \mathrm{Ps}_{\mathrm{s} .}$-Asc. 255 Stangl: persuasisse bane legem dicitur Opimius.

${ }^{71}$ Cic. Verr. 2.1.155: Petita multa est apud istum praetorem a Q. Opimio; qui adductus est in iudicium, verbo quod, cum esset tribunus plebis, intercessisset contra legem Corneliam, re vera quod in tribunatu dixisset contra alicuius bominis nobilis voluntatem ("A charge involving a fine was brought to this praetor [C. Verres] regarding Q. Opimius, who was brought to trial nominally because, when he was tribune of the plebs, he used his veto contrary to the Lex Cornelia, but in truth because during his tribunate he spoke against the will of some noble").

${ }^{72}$ Cic. Verr. 2.1.155-157. The trial lasted three hours; Verres reputedly bankrupted Opimius with fines. 
arrival, and recalled the masses, by then unaccustomed to contiones, to a semblance of their old habit. ${ }^{n 3}$ This statement is plainly exaggerated, as Cicero's Roman audience- and we today - could easily name several former tribunes known to have held contiones between 81 and $75 ;{ }^{74}$ but none would disagree that tribunician contional activity had been in a serious state of decline since Sulla's reforms, or that Quinctius' activity represented a comprehensive revival of the tribunate's "contional habit" on a scale not seen since the days of the pre-Sullan tribunes. Indeed, it may have been this revival that precipitated the decision to move the praetor's tribunal.

\section{TRIBUNES AND THE CONTIONAL HABIT}

To fully appreciate how Quinctius' revival of the contional habit could have created a very real, even urgent need to reapportion space within the Forum, it is necessary to understand the nature of tribunician contiones in their pre-Sullan context. An historical overview of their outward expansion from the Comitium, where they were originally held, to ever larger areas of the Forum will illustrate their potential magnitude in terms of area occupied and numbers in attendance. Next comes an assessment of their frequency and noise levels, followed by consideration of the penalties tribunes might impose on non-tribunes for interfering with their contiones, whether inadvertently or on purpose. Understanding how all of these factors could impact praetors operating in the same general area will go some way towards explaining the need to move their tribunal - and those of their peers- to the opposite end of the Forum late in 75 or early in $\mathbf{7 4 .}$

It must first be observed that by the mid-second century, tribunician activities had expanded well beyond the Comitium, and would soon come into direct conflict with those of the praetor, if they had not already done so. Indeed, it seems that tribunes may have been encroaching on the Forum, at least in their legislative activities, from a much earlier period. Taylor cogently argues that tribunes speaking from the Rostra had been facing out towards the Forum proper-instead of towards the Comitium and Curia - since at least $338,{ }^{75}$ when the suggestum on the southern edge of the Comitium was decorated with rostra

${ }^{73}$ Cic. Cluent. 110: [Quinctius] ... rostra iam diu vacua locumque illum post adventum L. Sullae a tribunicia voce desertum oppresserat, multifudinemque desuefactam iam a contionibus ad veteris consuetudinis similitudinem revocarat.....

${ }^{74} \mathrm{Cn}$. Sicinius in 76 (Cic. Brut. 216-217) and Q. Opimius in 75 (Cic. Verr. 1.155-157) held notable contiones, cf. ps.-Asc. 255 Stangl; Schol. Gron. 341 Stangl. It is possible that the obscure but much deprecated $\mathrm{M}$. Terpolius in 77 also gave a contio or two, but we only know of him because Asconius (81C) remarks that "he appears to have been the most contemptible man elected of those who had been tribunes of the plebs between the breaking of the tribunician power by Sulla and its restoration by Pompey" (contemptissimum nomen electum esse ex eis qui tr.pl. fuerant post infractam tribuniciam potestatem a Sulla, ante restitutam a Cn. Pompeio apparet).

${ }^{75}$ Taylor 1966: 21-25, 108. Morstein-Marx (2004: 46, n. 38) rejects Taylor's theory on the grounds that the tribes still voted inside the Comitium at that time. It seems unreasonable, however, to assert that just because the voting process took place within the Comitium, all contiones held on 
from the fleet that consul C. Maenius captured at Antium. ${ }^{76}$ Indeed, one might even suppose that tribunes began speaking out into the Forum once the first praetor installed his tribunal on the edge of the Comitium (ca 366) to direct the noise of their speaking and their crowds of listeners away from this important new magistrate and his affairs. Taylor also demonstrates on philological grounds that the change instituted in 145 by tribune C. Licinius Crassus was not, as often supposed, turning to the Forum to speak to contiones, but reorienting the voting assemblies: he was apparently the first tribune to perform a formal rogation, or act of legislation, in the main area of the Forum, the so-called septem iugera forensia. ${ }^{77}$ Crassus thus transferred a major portion of the legislative process from the incommodious Comitium, and committed it to the space in front of the Rostra's eastern corner. ${ }^{78}$ This innovation was presumably made feasible by the recent removal from the Forum of a large number of unauthorized honorific statues, in accordance with a censorial edict in $158 ;{ }^{79}$ it may even have precipitated, or been precipitated by, a new reconstruction of the Rostra itself. ${ }^{80}$

any but a comitial day had to be similarly confined (if they ever were), particularly those not related to legislative issues, for example, ad hominem diatribes.

${ }^{76}$ Liv. 8.14.12; Plin. NH 34.20.

${ }^{77}$ Varro RR 1.2.9: C. Licinius tr. pl. cum esset ... primus populum ad leges accipiendas in septem iugera forensia e comitio eduxit ("When Gaius Licinius was tribune of the plebs .... he first led the people out of the Comitium into the main area of the Forum for the purpose of hearing law proposals"); and Cic. Am. 96: primus ... in forum versus agere cum populo ("he [C. Licinius] first established the practice of facing the forum to address the people concerning legislative matters"); Taylor 1966: 21-25, 108. Thommen (1995: 363) avers that Crassus' reorientation of rogations away from Comitium and Curia contained an ideological message of disrespect for the senate, given the popularis nature of some of his legislation. This is perhaps overstated, as Crassus may simply have been addressing the problem of crowds too large for the Comitium's restricted space. Morstein-Marx (2004: 45-47) suggests that Crassus moved both the pre-comitial contio and the subsequent voting into the main area of the Forum, rather than "turning a pirouette on the Rostra between final contio and vote." In any case, they would have had to cast their votes in a consecrated area, which the Forum in general was not.

${ }^{78}$ See Purcell 1995: 333 on misguided attempts, such as the one by Platner and Ashby (1929: 234), to link with Crassus' innovations in 145 the transferral of the Praetor's tribunal from the Comitium to a location near the Puteal Scribonianum, based on the evidence of Porph. ad Hor. Ep. 1.19.8. See also above, 329 , n. 33.

${ }^{79}$ Plin. NH 34.30: L. Piso prodidit M. Aemilio C. Popilio iterum cos. a censoribus P. Cornelio Scipione [Nasica] M. Popilio statuas circa forum corum, qui magistratum gesserant, sublatas omnes praeter eas, quae populi aut senatus sententia statutae essent ("L. Piso recorded that, in the second consulship of M. Aemilius and C. Popilius (158 B.C.E.), all the statues round the forum of those who had held magistracies were removed by censors $\mathrm{P}$. Cornelius Scipio [Nasica] and M. Popilius, except those which had been erected in accordance with a resolution of the people or of the senate"); see also Auct. De vir. III. 44: [Scipio Nasica] censor statuas, quas sibi quisque in foro per ambitionem ponebat sustulit ("As censor he [P. Scipio Nasica] removed the statues which, due to ambition, certain men had erected in the forum to honor themselves").

${ }^{80}$ Carafa (1998: 75-80, 86-88, 148-151) reexamined the Rostra's stratigraphy and found that the familiar curved-are version of the Rostra was built in the mid-second century. This suggests a possible connection between the Rostra's modification and Crassus' innovation, as noted by Morstein-Marx (2004: 47, n. 40). 
The important implication here is that all the special equipment, including the huge temporary wooden voting bridges on which voters walked up to the consecrated voting area atop the Rostra, and all the personnel- such as bailiffs, heralds, urn-keepers, and other tribunician attendants ${ }^{81}$ - and the myriad citizens who showed up to vote, would often be situated for an extended period in this important space. Additionally, if there occurred any interruption of the voting process or multiple adjournments of pre-comitial contiones, this part of the Forum could be inconveniently occupied for several consecutive days. ${ }^{82}$

The problem of crowding in the Forum would sometimes be alleviated by the holding of legislative contiones and comitia in the Area Capitolina on the Capitoline Hill, as our sources indicate. ${ }^{83}$ But this area was somewhat restricted-it could be "occupied" by groups wishing to prevent access to other voters ${ }^{84}$ and seems to have been abandoned as a site for such activities shortly after $121 .^{85}$ Perhaps this was due to the availability of another site nearer to the heart of the Forum: the Temple of Castor, newly rebuilt in 117 with an impressive façade and high podium that provided both an excellent new speaker's platform and a consecrated voting area. $^{86}$ This site, however, served only as a secondary location for tribunician contiones and legislative activities. Recent studies have demonstrated that, despite

${ }^{81}$ praecones, custodes and rogatores.

${ }^{82} \mathrm{~A}$ famous example occurred in 167 , albeit on the Capitol, when a pre-comitial contio regarding ratification of L. Aemilius Paullus' triumph ran until dusk and was adjourned to the next day (Livy 45.35.4-36.10; Per. 45; Plut. Aem. 30.3-32.1; cf. Vell. 1.9.6). On the use by tribunes of obnuntiatio, the proclamation of bad omens to vitiate official proceedings of any type, see Kondratieff 2003: 556 s.v. "obnuntiatio" for over a dozen known occurrences between 180 and 44 (ten of which occurred in the $50 \mathrm{~s}$ ).

${ }^{83}$ For more than a dozen instances of contiones or comitia on the Capitol between 212 and 66 , see Kondratieff 2003: 589-590 s.v. "topography - Capitol (general)." Many of these contiones and associated comitia had to do with extra-pomoerial affairs, i.e., war, peace, triumphs, and the like, for which see the previous note. Sandberg (2001: 119-122, 139-141) discusses popular legislation by tribunes outside the pomoerium, which in the republic did not enclose the Aventine, the Capitoline (at least not the Arx), or the Circus Flaminius and the Campus Martius. For the location of the Capitol outside the pomoerium, see: Richardson 1992: 70 s.v. "Capitolinus, Mons"; 294 s.v. "Pomerium"; and 330 s.v. "Regiones quattuor."

${ }^{84}$ Livy (45.36.6) notes that on the day to vote for L. Aemilius Paullus' triumph (above, n. 82), soldiers inimical to their commander "filled the Capitol with so great a crowd that no one else could approach to cast his vote" (milites tanta frequentia Capitolium conpleverunt, ut aditus nulli praeterea ad suffragium ferendum esset). Cf. Liv. 34.1.1-6 for extreme crowding in this area during contiones about the abrogation of the lex Oppia in 195.

${ }^{85}$ Taylor (1966: 46) notes that voting on the Capitol apparently ended in 121 with the rogation of tribune M. Minucius Rufus (App. B. Civ. 1.25; Plut. CG 13.1.3). One known exception exists: on the night of 31 Dec. 67, tr. pl. C. Manilius passed a law on the Capitol allowing freedmen to vote in their patrons' tribes; on 1 Jan. 66 the new consuls annulled the law because it had been promulgated and voted into effect on the same day (Cic. Corn. 1, fr. 8-10, 16, 47, Mur. 47; Asc. 45, 64-65, and 76C; Varro LL 6.20; Gell. 10.24.3; Dio 36.42.2-3).

${ }^{86} \mathrm{~L}$. Caecilius Metellus Delmaticus rebuilt the Temple of Castor (Cic. Scaur. $46=$ Asc. $28 \mathrm{C}$; Cic. Verr. 1.154; Plut. Pomp. 2.4); later, C. Verres made repairs (Cic. Verr. 1.129-154, 3.41, 5.186). In general, see Nielsen and Poulsen 1992; Noreña 2002a; Morstein-Marx 2004: 47-55, 57-59. 
the temple's excellent accommodations, the old Rostra remained by far the preferred location for contiones (except for those at the Rostra Castoris to report senate proceedings within the Temple of Castor itself) ${ }^{87}$ But even the occasional presence of tribunician contiones and voting assemblies with all their apparatus in the southeastern corner of the Forum could have been a hindrance to other magistrates, whose ability to perform their duties at tribunals in the same general area might have been significantly hindered.

Also worth considering is the potential magnitude of, and disruption caused by, contional gatherings, particularly those concerning crucial political issues. Diodorus provides a vivid description of the mass support mobilized by Tiberius Gracchus and Marcus Octavius in 133 during their contest over Gracchus' proposed lex agraria (Diod. 34/35.6.2 [tr. F. R. Walton]): ${ }^{88}$

Since the strength on both sides was evenly balanced, and the scales tipped now this way, now that, the two parties, being assembled many thousands strong, clashed violently, and in the public assemblies there appeared billowing forms and patterns like waves on the sea. $^{89}$

That Diodorus' description is not mere poetic hyperbole seems indicated by the fact that on numerous occasions Cicero also compared impassioned contio audiences to winds, storms, and the sea. ${ }^{90}$ Indeed, such analogies should not be surprising from any speaker viewing a jam-packed Forum from the vantage point

Morstein-Marx (2004: 58 and n. 86) points out that the earliest directly attested examples of contio and comitia held at the Temple of Castor occur in 62, for which see Plut. Cat. Min. 26-29. Nevertheless, there is some evidence for earlier votes taken in that location: Cic. Or. 2.397 refers to two tribunes of 103, L. Cotta and T. Didius, driven from the Temple of Castor and Pollux while attempting to veto a tribunician rogation: vi pulsum e templo $L$. Cottam et $T$. Didium, cum intercedere vellent rogationi, nemo poterat negare. Cf. Pina Pola 1989: 281-282 no. 208. App. B. Civ. 1.64 notes the expulsion of tribunes from the Temple of Castor's rostra while attempting to veto Cinna's proposal to enfranchise the Italians in 87; cf. App. B. Civ. 1.49; Vell. 2.20.2-3; Schol. Gronov. 286 Stangl.

${ }^{87}$ Morstein-Marx 2004: 58-59. An exception occurred in 44, when Caesar's reconstruction of the western Forum caused all contiones to be moved to the Temple of Castor. Contiones to report on senate proceedings at the Temple of Castor may date as early as 159 , as indicated by a fragment of the $S C$ de Tiburtibus: CIL $12.586=$ ILS $19=$ ILLRP 512, line 1.

${ }^{88}$ Morstein-Marx (2004: 160-203) argues that these were not debates but well-orchestrated mass demonstrations of adherents to a particular legislative package to convince the opposition that the "Roman People" desired that the bill be passed, and thus persuade the opposition to support it; see too David 2006: 423-424 in support of this position. If such is the case, then Gracchus and Octavius provide an unusual example of opposing tribunes mobilizing nearly equal groups representing two different versions of "the people's will."

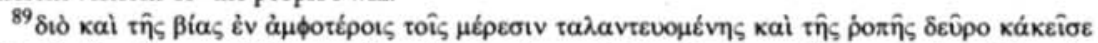

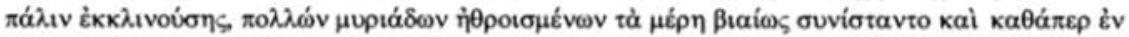

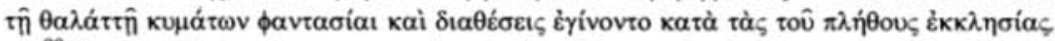

${ }^{90}$ For Cicero's use of stormy metaphors in describing contional audiences, see Cic. Mil. 5, Clu. 77, 130, Sest. 140, Pbil. 2.17, Har. resp. 43; see also Quint. Inst. 8.3.80. 
afforded by the Rostra-more than three meters above the Forum's pavement. ${ }^{91}$ Although estimates for the size of contional crowds are a matter of much debate, we can safely assume that a particularly well-attended meeting in the Forum proper might consist of somewhere around ten thousand souls, and perhaps double that number for super-contiones, whose attendees had to jostle and jam themselves onto temple podia or into the loggias of surrounding basilicas and tabernae just to get a glimpse of the proceedings. ${ }^{92}$

In addition to their size, the frequency of contiones was also a problem. Plutarch recounts the near-daily public spectacle of Gracchus dragging Octavius before the popular assembly in a vain attempt to persuade or coerce him into withdrawing his veto against the proposed lex agraria. ${ }^{93}$ Such frequent and disruptive meetings were not exceptional, nor required only by Gracchus' momentous proposal. Cicero claims that in his youth, during the $90 \mathrm{~s}$ and $80 \mathrm{~s}$, he witnessed the activities of tribunes who "all but lived on the Rostra" and "addressed the populace almost daily."94 Throughout his adult years, Cicero would witness and document the fact that this tribunician habit, in abeyance only during the half-decade following Sulla's dictatorship, had not only returned with a vengeance in 74 , but would continue down into the $40 \mathrm{~s} .{ }^{95}$ Tacitus also writes of the incessant holding of contiones by tribunes of the late republic. ${ }^{96}$ Some, he informs us, even slept near

${ }^{91}$ Platner and Ashby 1929: 450-451 s.v. "Rostra"; cf. Richardson 1992: 334-335 s.v. "Rostra"; Pina Polo (1996: 23-25) notes the visual hierarchy created by raising magisterial speakers so high above the heads of the listening crowd; cf. David 2006: 422-423.

${ }^{92}$ Thommen's (1995: 364) estimate of a 1,000-occupant capacity for the Comitium seems far too low. Other modern estimates range between 3,000 (Carafa 1998: 140, n. 52) and 6,000 (MacMullen 1980: 456). Middle Forum occupancy estimates range from a skimpy 6,000 (Thommen $1995: 364$ ) to a packed 20,000 (MacMullen 1980: 455-456); see most recently Morstein-Marx 2004: 45 and n. 36. MacMullen's higher estimate seems feasible, and may have been exceeded on occasions when temple podia and tabernae loggias were crammed with onlookers.

${ }^{93}$ Plut. TG 10.4 .

${ }^{94}$ Cic. Brut. 305 refers to the activity of the tribunes of 91/90: et bi quidem babitabant in rostris. Brut. 306 refers to P. Sulpicius, tribune in 88: tum P. Sulpici in tribunatu cotidie contionantis. Morstein-Marx (2004: 9 and n. 40) also refers to this striking passage, but fails to note that it relates specifically to tribunes rather than to magistrates in general (2004: 124, 177 and $\mathrm{nn} .75-76)$.

${ }^{95}$ Other references to daily assemblies (contiones cotidianae) all relate exclusively to tribunician contiones held after the restoration of tribunician dignitas in 75 and tribunicia potestas in 70: Cic. Cluent. 93 and 103 refer to L. Quinctius' activities as tribune in 74; Cic. Sest. 39 and 42 refer to P. Clodius' "daily" anti-Ciceronian contiones during his tribunate in 58; Cic. Mil. 12 refers to T. Munatius Plancus' tribunician activities in 52; and Asc. 51C similarly refers to Plancus' constant harangues along with those of his tribunician colleagues Q. Pompeius Rufus and C. Sallustius Crispus.

${ }^{96}$ Tacitus' description in Dial. 40.1 of incessant (adsiduae) contiones during the late republic must also refer to tribunician orators: he characterizes them as having been held by fiery orators inveighing against the leading men (potentissimi), orators who would not stick at attacking a Scipio (Africanus, attacked by the Petilli, tribunes in 187; Aemilianus, harassed by C. Carbo, tribune in 130, among others), or a Sulla (attacked by P. Sulpicius, tribune in 88), or a Pompeius (a favorite target of several tribunes, including P. Clodius in 58, for which see, for example, Plut. Pomp. 48.5-7). In short, the 
the Rostra in order to seize upon it at daybreak before their opponents could do likewise. ${ }^{97}$

The frequent oratory of some tribunes may have been concerned less with the politics of the day, and more with their own political futures. It is less likely that some tribunes held frequent contiones simply to make a name for themselves with, perhaps, the secondary goal of practicing and improving their skills of oratorical persuasion. ${ }^{98}$ That is not to say that they sought to emulate the most polished or eloquent speakers of their day. Cicero opines that the speaking styles of many tribunes who frequently addressed the people, although unworthy of an expert audience's ears, were perfectly suited for "turbulent contiones" or attuned "to the ears of the ignorant." cultivated by choice is quite clear. Cicero himself points out that popular oratory was necessarily aimed at, and had to win the approval of, the largest contingent of the crowd, i.e., the vulgus (rabble). ${ }^{100}$ More importantly, no matter what others thought of their skills or relative status, many tribunes who lacked oratorical polish took repeated advantage of their right to address and persuade the populace virtually at will, some eventually finding a stylistic niche that worked for them. ${ }^{101}$

context of 'Tacitus' reference to incessant contiones is surely meant to recall those held by tribunes of the plebs, not by other magistrates. Cf. Pina Polo 1989: 86. Morstein-Marx (2004: 9 and n. 40) also notes that more than one contio could be held in the space of a single day, though by different officials, as in Asc. 49C and Cic. Att. 2.24.3; Vat. 24, 26. Pina Polo (1989: 308-309, nos. 346-351) notes that six contiones were held in the four days following Caesar's assassination.

${ }^{97}$ Tac. Dial. 36.3: binc contiones magistratuum paene pernoctantium in rostri. He may have had in mind P. Aquillius Gallus, tr. pl. 55, who actually slept in the Curia in order to be first on the Rostra next morning to oppose tribune C. Trebonius' rogation on Crassus' and Pompey's commands; Trebonius himself locked his colleague in the Curia to preempt his dissuasio (Plut. Cat. Min. 43.4; Dio 39.32.3, 39.34.1, and 39.35.3-36.1).

${ }^{98}$ Of course, some tribunes did retire from the Rostra in discouragement: C. Scribonius Curio (the Elder), cos. 76, tr. pl. 90, gave up speaking while tribune after his entire audience melted away, disgusted by his ungainly gestures and flailing on the Rostra (Cic. Brut. 216-217, 305; cf. Brut. 192). See now David 2006: 421-422 and passim on the pressure to develop competency in rhetorical and oratorical skills in the late republic.

${ }^{99}$ Cicero (Brut. 223) judges that the speaking styles of $\mathrm{Cn}$. Papirius, tr. pl. 92, M. Marius Gratidianaus, tr. pl. 88, M. Lollius Palicanus, tr. pl. 70, and numerous others of a similar cast were unworthy of an expert audience's ears, but suitable for tumultuous, ignorant assemblies: $\mathrm{Cn}$. Carbonem M. Mariam et ex eodem genere compluris minime dignos elegantis conventus auribus aptissimos cognovi turbulentis contionibus... aptior etiam Palicanus auribus imperitorum. The interested reader may find collected notes on the forensic styles and habits of more than eighty tribunes between 212 and 44 in Kondratieff 2003: 582-585 s.v. "style-oratory, verbal self-presentation, wit" (the actual references to the sources are contained in Kondratieff 2003: 347-507, "Appendix A: Chronology of Tribunes," passim).

${ }^{100}$ Cic. Brut. 191: Oratio popularis assensum vulgi debet movere. On the matter of varied speaking styles, and the deliberate choices between rusticitas, urbanitas, and other styles used by Roman orators, see in general David 1980, 1983; Corbeill 1996; Aldrete 1999; and Kondratieff 2003: 228-255, focusing specifically on tribunician examples.

${ }^{101}$ Cicero (Brut. 226-227) informs us that despite a triple disadvantage of poor speaking voice, tasteless mannerisms, and lackluster reputation, P. Antistius won acclaim through forensic persistence 
That frequent public oratory was in fact the norm for tribunes seems implicit in Cicero's surprise at the taciturnity of L. Licinius Crassus Orator during his tribunate in 107: he was so quiet a tribune that no one would have known he had been one, had not Lucilius satirized the dinner he shared during his tribunate with Granius the praeco. ${ }^{102}$

In addition to anecdotal evidence on the frequency of tribunician contiones, recent studies demonstrate that, in relative terms, tribunes were the dominant presence on the Rostra: at least fifty percent of all contiones reported for the late republic were held by tribunes. ${ }^{103}$ This is a striking statistic, but one that is probably still too low due to under-reporting. Our sources for the late republic and for the classical republic as well-failed to record any but the most notable tribunician contiones or contional themes, for example, those in which significant, precedent-setting, or controversial bills were discussed, or wherein great men were publicly interrogated, maligned, or indicted before the people, while thousands of contiones held on routine matters are missing from the record. For example, Livy chooses to report the constant public railings of M. Metilius, tr. pl. 217, against dictator Q. Fabius Maximus and his delaying tactics; ${ }^{104}$ recounts how Q. Baebius Herennius, tr. pl. 216, frequently denounced the senate to support the controversial consular candidacy of kinsman M. Terentius Varro; ${ }^{105}$ and relates

during his tribunate in 88 . Antistius' particular skill-which brought him many requests for assistance after his tribunate - turned out to be in "penetrating arguments" rather than eloquence or grace (P. Antistius fuit, rabula sane probabilis, qui multos cum tacuisset annos neque contemni solum sed inrideri etiam solitus esset, in tribunatu primum contra $C$. Iuli illam consulatus petitionem extraordinariam veram causam agens est probatus; et 00 magis quod eandem causam cum ageret eius conlega ille ipse Sulpicius, bic plura et acutiora dicebat ... actio paulum cum vitio vocis tum etiam ineptiis claudicabat).

${ }^{102}$ Cic. Brut. 160: sed ita tacitus tribunatus ut, nisi in eo magistratu cenavisset apud praeconem Granium idque nobis bis narravisset Lucilius, tribunum plebis nesciremus fuisse. Cf. Lucil. 20.595-622, apparently from the satire written about the dinner. Note that the lex Licinia regulating the weight of bought food consumed per day, and mentioned in Lucil. fr. 599, relates to P. Licinius Crassus Dives.

${ }^{103}$ See Morstein-Marx 2004: 9-12, 34-35, 38-42, and n. 14 on the importance of contiones and their centrality to public life. For the greater frequency of tribunician contiones in relation to those held by other magistrates in the late republic, see in particular Pina Polo's (1996: 52) estimate that 50\% or so of known late-republican contiones were held by tribunes and that the approximately ninety known contional speakers for that period break down to about $60 \%$ tribunes, $30 \%$ consuls, and $10 \%$ praetors.

${ }^{104}$ Livy (22.25.1) begins de iis rebus [Fabius' tactics] persaepe et in senatu et in contione actum est, with Metilius' motion to extend a dictatorship to M. Minucius in the next sentence. Plutarch (Fab. 8.3) points out that Metilius multiplied the effect of his own diatribes by inciting several tribunes to rouse the plebs with "a thousand stories" against Q. Fabius Maximus Cunctator for his delaying tactics.

${ }^{105}$ Liv. 22.34.2-35.1. At this stage in Rome's history tribunes took office on Dec. 10, consuls in March of the following year. Since elections for consuls often were not held until February or March, tribunes friendly to a particular candidate could agitate in his favor, perhaps in hopes of inculcating useful gratia in the new consul for the remaining nine months of their tribunician year (see, e.g., Liv. 39.32.5-13, esp. 39.32.12, for the tribunes of 184 assisting one or the other of the consular candidates). The date on which consuls entered office changed to Jan. 1 in 153 (Liv. Per. 47) apparently due to the leges Aelia et Fufia, which regulated the dies comitiales for legislation and magisterial elections (Cic. Har. Resp. 58, Sest. 33, 56, 78-79, 114, 129, Vat. 16-18, 23, Dom. 39, Prov. Cons. 45-46, Pis. 9-10, 
that C. Publicius Bibulus, tr. pl., caused the plebs to share his hatred of M. Claudius Marcellus through constant harangues against him. ${ }^{106}$ But he rarely mentions the series of contiones that surely preceded the many tribunician bills voted on during that same period, even for laws whose final passage he does report. Add to this under-reporting a simple fact: as the ten tribunes of any given year were more or less city-bound, whether by law or tradition (unlike pre-Sullan curule magistrates), they clearly had far more time, opportunity, and motivation to hold contiones than any other officers privileged to do so, whether to mobilize support for or against legislative proposals covering a huge range of issues, to praise or denounce the candidacy or activities of a particular politician or general, or even to relate the minutiae of senate meetings. ${ }^{107}$ The possibilities were endless. It seems reasonable to conclude that, before Sulla's reforms, tribunician affairs could frequently occupy the western Forum - sometimes the entire Forum-a problem that would be particularly acute in times of heightened political activity.

We can conclude from the foregoing that the urban praetor would frequently have found it difficult to conduct affairs at his own tribunal, especially when a popular tribune capable of attracting very large audiences was addressing an assembly nearby. The praetor's predicament would be intensified if that tribune were also capable of eliciting enormous roars from the crowd; ${ }^{108}$ or worse, if he had supporting him a claque of noisemakers to drown out the addresses of his opponents. Perhaps the most spectacular example of extreme noise levels in a contio occurred in 67 during a pre-comitial contio for the lex Gabinia. The crowd had become so loud in shouting down the opponents of this law that tribune L. Roscius had to make his disapproval of the bill known through hand gestures. The story goes that the crowd roared so thunderously at Roscius that a raven flying overhead was stunned by the sonic shock and fell into the crowd below; more believable, and relevant, is the claim that the deafening noise intimidated

Phil. 2.81-83, 99, Att. 1.16.13, 2.91, 4.3.3, 16.5, 17.4; Asc. 8C; Broughton 1951-86: 1.452), thus ending this particular type of political symbiosis.

${ }^{106}$ Liv. 27.20.11: inimicus erat [M. Claudio Marcello] C. Publicius Bibulus tribunus plebis, is iam a prima pugna quae aduersa fuerat adsiduis contionibus infamem inuisumque plebei Claudium fecerat.

${ }^{107}$ Millar 1998: 209; Kondratieff 2003: 530-536, with over two hundred examples of tribunician contiones (or series of contiones) from 220 to 30 , held or participated in by one or more tribunes, known and anonymous, categorized by theme. Cf. Morstein-Marx 2004: 8, 115-116 on tribunes addressing the crowd regarding the minutiae of senate meetings, as in Asc. 44-45C (T. Munatius Plancus, 1 March 52). For a dimmer view of the relevance of these contiones (although frequency, not relevance, is the theme here), see Mouritsen 2001: 38-62.

${ }^{108}$ Cicero (Orat. 213-214) notes how a clever metrical statement by C. Papirius Carbo, tr. pl. in 90, elicited a roar of approval from the appreciative crowd. See most recently Morstein-Marx 2004: 138, $149-150$ and nn. 161-162, 168-169, and 180 citing additional examples of noisy contional crowds: the crowd's enormous roar of disapproval in 131 when Scipio Aemilianus proclaimed, in response to tr. pl. C. Papirius Carbo's question on the matter, that Ti. Gracchus had deserved to die as he did if revolution had been his plan (Vell. Pat. 2.4.4; Cic. Or. 2.106, Mil. 8); tr. pl. M. Cato's eliciting of a great shout from the crowd in praise of Cicero in 62 (App. B. Civ. 2.7; cf. Plut. Cat. Min. 23.5-6; Cic. Fam. 15.4.11); see also, in general, Tac. Dial. 39-40. 
Roscius into utter immobility. ${ }^{109}$ But this remarkable example is not entirely unique. Valerius Maximus describes a tribunician contio held ca 103-100 in which the "clamor of the ignorant mob was shaking the whole forum." 110 In fact, such clamor was probably not remarkable at all, but a fairly typical example of contional management undertaken as an additional method for persuading or intimidating those in the crowd who did not yet support the presiding tribune's program. As Morstein-Marx cogently points out, a group of people hired as a "claque" could effectively drown out the opposition, as well as induce the uncommitted portion of the crowd to follow their lead, first in noise-making, then in decision-making. ${ }^{111}$ In effect, the claque became the crowd's "whip." If more than one such "whip" was in attendance, the noise could easily become deafening (as anyone who has attended a large and well-orchestrated public protest or rally can attest). ${ }^{112}$ Details of crowd management aside, the important point for our discussion is that such extreme noise levels - whether spontaneous, paid for, or a combination of the two- would have seriously interfered with the praetor's ability to perform his duties nearby.

All of these aspects of tribunician contiones - size, frequency, and noise-would have been sufficient to justify a reassignment of Forum space in anticipation of, or after the revival of, tribunician contiones in late 75 or early 74 . There may also have been another, perhaps only minor, consideration that contributed to the decision to move the praetor's tribunal: the problem of avocatio contionis, the calling away of a tribune's assembly. The sources preserve only a few examples of avocatio involving pre-Sullan tribunes, with only one known to have occurred between a tribune, L. Appuleius Saturninus, and a praetor, C. Servilius Glaucia. ${ }^{113}$ On a day when Saturninus was holding a contio, something about the judicial activity at the praetor's nearby tribunal-the matter being adjudicated, the oratory of an advocate, or the applause of the crowd surrounding the tribunal-attracted people away from Saturninus' contio. Enraged, the tribune seized the praetor's

${ }^{109}$ Dio 36.30.3-4; cf. Plut. Pomp. 25.6.

${ }^{110}$ Val. Max. 3.8.6: clamor imperitae multitudinis obstrepebat totum forum; cf. Auct. De vir. ill. 73.3-4. This contio was held by an unnamed tribune wishing to prove that $\mathrm{L}$. Equitius was the son of $\mathrm{Ti}$. Gracchus (Equitius was therefore a popular favorite of the plebs). He brought Equitius' putative aunt Sempronia onto the Rostra, but she staunchly denied that Equitius was her nephew, despite her interrogator's hostile expression and the crowd's clamor.

${ }^{111}$ Morstein Marx 2004: 133. See also 136-137 and 142-143 on "claptraps," originally groups from which orators elicited appropriate and noisy responses, and "applaudable messages" as a built-in feature of public (and tribunician) oratory; see also 135 and 165-166 on contional violence and the occupation of the area immediately around the Rostra by a speaker's core supporters to create the impression of unified support by drowning out other audience members with their applause and shouts (properly timed, no doubt), and to use threats and intimidation to suppress adversarial voices.

${ }^{112}$ See Cic. Q. Fr. 2.3 .2 for a contio during the trial of Milo in which both the pro-Clodius and pro-Milo crowds had sufficient supporters to raise disconcertingly loud shouts intended to fluster the other side's speaker.

${ }^{113}$ Badian (1984) discusses the problems of dating this event to 103 or 100. 
chair and smashed it to pieces. ${ }^{114}$ Our source attributes Saturninus' reaction to a desire to appear more popularis. Alternatively, we might see it as symptomatic of the physical violence he sometimes employed in his political activities. But it also constitutes a relatively mild response to what was considered a grave offense against tribunician dignitas. The gravity of such a violation of tribunician rights can be confirmed by other recorded instances of avocatio that incurred more serious consequences. In 169 tribune P. Rutilius indicted censor C. Claudius for perduellio (high treason) because he had "called away" a pre-comitial contio on Rutilius' proposal to void and re-let that year's censorial contracts. ${ }^{115}$ Although Claudius had only asked a herald to stop a heckler from interrupting his own dissuasio against the bill, Rutilius nearly secured the censor's conviction and exile on this charge. ${ }^{116}$ In 121 former tribune Gaius Gracchus was supposedly hauled before the senate for having called away the pre-comitial contio in which thentribune M. Minucius Rufus was proposing the abrogation of laws Gracchus had passed in the previous year. ${ }^{117}$ Lastly, in 91 tribune M. Livius Drusus had a client, or his viator, twist the neck of consul L. Marcius Philippus so hard that his nose and ears bled, all because the consul "had dared to interfere with him as he was addressing a contio. ${ }^{118}$ Drusus then personally dragged or drove the consul, still gushing blood, off to prison. Other examples may be adduced, but these suffice

${ }^{114}$ Auct. De vir. ill. 73: "Because he (the praetor Glaucia) had called away part of the people by adjudicating the law on the self-same day in which he (Saturninus) was holding a contio, Saturninus shattered Glaucia's chair, so that he would seem more popularis" (Glauciae praetori, quod is eo die, quo ipse contionem babebat, ius dicendo partem populi avocasset, sellam concidit, ut magis popularis videretur).

${ }^{115}$ Liv. 43.16.9-11: [cum] Claudio obstreperetur, audientiam facere praeconem iussit. Eo facto avocatam a se contionem tribunus [pl. P. Rutilius] questus et in ordinem se coactum ex Capitolio, ubi erat concilium, abit. Postero die ... [tr. pl. P. Rutilius] C. Claudio diem dixit, quod contionem ab se avocasset.

${ }^{116}$ See Liv $43.16 .3-16$ for the entire episode. See also Liv. 38.51-52 for the amusing Antiate account wherein Scipio Africanus blatantly called away the contio of two tribunes indicting him for embezzlement by inviting the audience to attend him while he celebrated the fifteenth anniversary of his victory over Hannibal at Zama. The entire assembly, including the tribunes' assistants, followed Scipio, so the tribunes accused him of inciting a "secession of the plebs ... from the tribunes" (Liv. 38.52.5: secessionemque eo die in Capitolium a tribunis plebis fecisset).

${ }^{117}$ Auct. De vir. ill. 65.5 (an admittedly problematic source): Minucio Rufo tribuno plebis legibus suis obrogante in Capitolium venit; ubi cum Antyllius praeco Opimii consulis in turba fuisset occisus, in forum descendit et imprudens contionem a tribune plebis avocavit; qua re arcessitus cum in senatum non venisset ("When Minucius Rufus as tribune of the plebs was opposing [C. Grachhus'] laws, [Gracchus] came to the Capitol; when Antyllius, herald of the consul Opimius, had been killed in the tumult, [Gracchus] descended to the forum and imprudently called away the assembly from the tribune of the plebs; when he was summoned to the senate for this action, he would not come"). See in general App. B. Civ. 12.5 and Plut. CG 13.1.3. See also Pina Polo 1989: 65-68 on avocatio. Morstein-Marx (2004: 39, n. 17) writes that C. Gracchus' offence in Auct. De vir. ill. 65.5 was his attempt to call his own contio since he held no magisterial powers (Gracchus was merely a IIIvir a.d.a). This late source may have missed the point, i.c., that the murder of the consul's praeco was the real issue of interest to the senate; but regarding avocatio, it would seem that the crux of the matter was that Gracchus called away a tribune's contio, not that he tried to hold his own gathering.

${ }^{118} \mathrm{Val}$. Max. 9.5.2: quia interfari se contionantem ausus fuerat. Valerius claims it was a client, not a viator, who twisted Philippus' neck, but 'Flor. 2.5 has Drusus' viator doing the dirty work; see also Auct. De vir. ill. 66.9. 
to indicate that Saturninus' smashing of the praetor's chair fits a larger pattern of retribution that could be inflicted by tribunes on those who diminished their dignitas through avocatio. ${ }^{119}$ More to the point, the chair-smashing incident may be taken as yet another indication that the space in the western end of the Forum was no longer sufficient for praetors-whose judicial activities often included stentorian orators and clamorous audiences ${ }^{120}$-and tribunes - whose contiones could produce intense, even overwhelming levels of noise- to conduct business there at the same time.

\section{MOVING THE PRAETOR'S TRIBUNAL: TIMING}

Why this problem of overlapping and conflicting spheres of activity was not resolved by reapportioning Forum space before 75 - for instance, around the time of Saturninus' tribunate-is uncertain, but the long delay between the problem's development and its resolution can be plausibly attributed to a variety of factors. Perhaps the subject was broached but shelved when other, more important affairs and crises-such as wars against Italians and Mithridates and among the Romans themselves-took center stage. Little is known about what went on in Rome during the domination of Cinna and other "Marians," but the sparse evidence for tribunician activity from 86 to 82 does give some indication that like-minded tribunes and praetors collaborated on potential solutions for, for example, economic problems besetting the state; perhaps they also cooperated in timing their activities so they would not coincide overly much. ${ }^{121}$ Of course, in 81 the potential for conflicting activities virtually evaporated when Sulla's legislation emasculated and effectively muzzled the tribunate. So, despite the increase in the number of quaestiones perpetuae in 81 , the praetor urbanus and other praetors adjudicating at their own tribunals probably would have experienced very little, if any, adverse impact on their activities from tribunician sources, at least down to 75. ${ }^{122}$ But once L. Quinctius revived the "contional habit" in late 75 or early 74,

${ }^{119}$ The sedition of publicani at the trial of Postumius of Pyrgi in 212 (Liv. 25.3.8-25.5.1) could be interpreted as an instance of avocatio, although the tumult occurred at the beginning of the comitia, not during the pre-comitial contio itself. See also n. 122, below.

${ }^{120}$ Just a few examples of noise during court cases need be noted here. For fired up, energetic, and loud forensic oratory: Cic. Brut. 317, Or. 32; for audience noise, including shouting abuse, hooting, and hollering: Cic. Or. 107, Att. 1.16.3, Fam. 8.2.1; Tac. Dial. 34.5, 39.4-5. For an example of claques hired for court cases in the early principate: Plin. Ep. 2.14.6-14.

${ }^{121} \mathrm{Cic}$. Off. 3.80 (tr. Miller): collegiumque praetorium tribuni plebi adbibuissent, ut res nummaria de communi sententia constitueretur .... conscripserunt communiter edictum poena atque iudicio constituenuntque, ut omnes simul in rostra post meridiem escenderent ("the tribunes of the plebs [of 85] summoned the college of praetors to council, in order to adopt by joint resolution a standard value for our currency .... In joint session they drafted an ordinance defining the penalty and ... methods of procedure in cases of violation .... and agreed they should all appear together upon the Rostra in the afternoon to publish it"). Cooperation indeed.

${ }^{122}$ One notable exception: Acilius Glabrio, tr. pl. 78, had the chair of a praetor smashed for not rising as he walked by the praetor's tribunal (Dio 36.41.1-2; Broughton 1951-86: 3.2; David and Dondin 1980). 
the potential for overlap and conflict between vociferous tribunes and adjudicating praetors re-emerged, and would have been too great to ignore any longer.

To solve the problem would require a reapportionment of space within the Forum. But who should be moved, and where? It would have made little sense to move the tribunes, since they required easy access to the "topography of punishment" to provide auxilium to those requesting it. Besides, moving the tribunes' offices would have reduced neither the frequency with which they used the Rostra for contiones, nor the attendant noise and crowding, and would therefore have afforded little relief to the praetor urbanus and his colleagues working nearby. The most sensible solution was to move the tribunal of the praetor urbanus to the east end of the Forum, more specifically to the Gradus Aurelii, which may have been built to accommodate juries in the area newly designated for the praetor's judicial work. The urban praetor's tribunal, meanwhile, would have been set just before the Gradus or (less likely) above them on the speaker's platform fronting the Temple of Castor. ${ }^{123}$ The tribunals of his peers overseeing the other quaestiones perpetuae were probably clustered in the same general area.

\section{MOVING THE PRAETOR'S TRIBUNAL: FUNCTIONAL IMPACT}

To assess the impact this change had on the praetor's ability to carry out his judicial functions and on the intercommunications between his tribunal and the tribunes' benches, one point to consider is that the distance from the Rostra to the praetor's tribunal had now been increased from perhaps 10 meters to more than 100 meters (325 feet), or greater than the length of a football field. Such a distance was probably sufficient to dampen significantly the noise of small- to moderate-sized contional crowds by the time it reached the praetor's tribunal. Likewise, the proceedings of the praetor's court would no longer have been clearly audible - and thus distracting - to those attending contiones at the Rostra; unless, perhaps, a particularly stentorian orator was defending or prosecuting someone, or an especially large and noisy crowd had gathered at the praetor's tribunal (at any one of the tribunals, in fact). Similarly, the distance between the old republican Rostra and the Gradus Aurelii would have diminished considerably the degree to which contiones and courts experienced mutually audible interference. Of course, the mere assertion that the transfer of the praetor's tribunal brought about such improvements is insufficient by itself, and requires some elaboration.

It must first be acknowledged that the Forum had no "quiet zones" in which judicial affairs could be conducted completely undisturbed. The eastern end of the

${ }^{123}$ Richardson (1992: 401 s.v. "Tribunal Praetoris") believes that praetors set their wooden tribunals on the ends of the various temple podia and speakers' platforms in the Forum, and that the tribunals themselves would thus only have to be a few inches high. Nielsen (1992: 113) points out that the front portion of the Temple of Castor's speaker's platform was approximately six Roman feet high, which would mean that the urban praetor's tribunal would be, at the very least, 6.5 Roman feet above the level of the Forum pavement. This is too high for Frier (1985: 62), who believes that these tribunals generally stood no more than one meter above ground level. 
Forum was not only the location of the various tribunals in Cicero's day-each thronged by its own smallish crowd of lictors, clerks, petitioners, and advocates whenever the praetor was present, not to mention juries and a corona of onlookers during trials ${ }^{124}$ - but also the regular resort of bankers, shopkeepers, and their clientele in the tabernae located around the Forum's perimeter. ${ }^{125}$ Thus, an orator at one of the tribunals had to be capable of making himself heard not only above the hubbub of the attendant crowd, but also above the pervasive hustle and bustle of the Forum's commercial activities; hence Cicero's remark that "a great mass of people and the noisy hubbub of the Forum call for an energetic orator who is fired up, lively, and of full voice." 126

Of course, forensic orators and their audiences were themselves responsible for a considerable amount of noise: Cicero remarks more than once on "mighty applause" greeting an advocate's excellent turn of phrase or the "uproar" and "tremendous shouts" of a displeased audience, the very sort of thing that might have attracted Saturninus' contio away to Glaucia's tribunal in earlier days. ${ }^{127}$ Such outbursts, however, were probably only intermittent and much less annoying or distracting to those speaking at tribunals roundabout than the constant shouting or repetitious chanting by claques that might occur in the vicinity of the Rostra. ${ }^{128}$ Moreover, a court's location out in the open allowed some of the noise it generated to dissipate into the air, mitigating its intrusive effect on other, nearby tribunals (though weather conditions could pose additional problems for orators). ${ }^{129}$ Only after courts were moved indoors do we hear of orators abandoning their speeches

${ }^{124}$ For the praetoria turba, see Cic. Verr. 2.1.138; see Frier. 1985: 62 and n. 59 on the crowd at a practor's tribunal.

${ }^{125}$ Purcell (1995: 333-334) discusses the economic life of the Forum down to the last decades of the republic. On the various tabernae in the Forum Romanum, see Coarelli 1992: 39-53, 91-119; Papi 1999a, 1999b.

${ }^{126}$ Cic. Brut. 317: Acrem enim oratorem, incensum, et agentem at canorum, concarsus bominum forique strepitus desiderat. Cf. Cic. Or. 32: "I have even met a man who desired to be like Xenophon, whose voice is sweeter than honey but very far removed from the noise of the forum" (nactus sum etiam qui Xenopbontis similem esse se cuperet, cuius sermo est ille quidem melle dulcior, sed a forensico strepitu remotissimus).

${ }^{127}$ Cic. Or. 107: Quantis ... clamoribus; Att. 1.16.3: clamoribus maximis; and Fam. 8.2.1 (early June, 51) to Caelius on the reaction of the audience at the trial of M. Valerius Messalla Rufus (cos. 53), when Messalla's narrow acquittal was announced: "Naturally they attacked the jurors with tremendous shouts and showed plainly that this could not be borne" (clamoribus scilicet maximis iudices corripuerunt et ostenderunt plane esse quod ferri non posset).

${ }^{128}$ Peterson and Gross (1978: 33) demonstrate that the level of annoyance at sounds that interfere with speech increases in direct proportion to the duration of the interfering sound itself; thus, short bursts of sound such as spontaneous laughter would be less annoying (and intrusive) than constant chanting or unending applause.

${ }^{129} \mathrm{On}$ the propagation of sound in and absorption by air, and on the increase or decrease of that absorption under differing atmospheric conditions, such as wind and/or humidity, see White 1975: 58-61. Quintilian (Inst. 11.3.27) teaches that orators ought to practice speaking in all sorts of weather conditions, as a good advocate should not abandon his client's cause on account of wind, rain, heat, or cold. 
in frustration due to uproar from a nearby tribunal; the sound, apparently, could be amplified beyond tolerable levels when it reverberated off the stone surfaces of the enclosed space. ${ }^{130}$

That orators and audiences of Cicero's day managed to carry on despite the ambient noise of the Forum and nearby courts indicates that they had been conditioned to, and thus had a fairly high tolerance for, what today might be considered highly disruptive noise levels. ${ }^{131}$ It also points up the fact that the transfer of the urban praetor's tribunal did not need to solve entirely the problem of overlapping crowds or audiences, or to eliminate completely any audible interference: it needed only to ameliorate the conditions under which the praetor conducted his public business, which it surely did. Recall that when the praetor's tribunal stood on (or in) the Comitium, and tribunes spoke towards the Forum, contional audiences faced both tribune and tribunal; thus, crowds and claques engaged in orchestrated shouting matches directed their clamor not only at the Rostra, but also at the praetor's tribunal just across the Comitium from the Rostra. In the eastern end of the Forum, however, the praetors were now behind and a football-field's length away from the contional throng, where they surely enjoyed some relief from the intense din of contiones now directed away from them. ${ }^{132}$

To put all of this into more scientific terms, merely reorienting the praetor's tribunal away from the source of the most offensive noise interference took advantage of what modern acoustics experts call the Masking Level Difference (MLD), which may be summarized as follows: "When speech and an interfering sound are separated widely in direction, the intelligibility of speech is greater than if the speech and noise are received along the same path." ${ }^{133}$ The effect of such reorientation alone can cause a significant drop in the level of interfering noise one experiences (approximately $7 \mathrm{~dB}$ ). ${ }^{134}$ The MLD effect is enhanced further when the listener is induced to concentrate his or her attention on the speaker

${ }^{130}$ Plin. Ep. 2.14.10-11; Quint. Inst. 12.5.6: in basilica Iulia . . . omnia clamoribus fremerent. Peterson and Gross (1978: 20) point out that an enclosed space with reverberant surfaces produces noise that is far more annoying to listeners because it seems to be coming from all directions.

${ }^{131}$ See Peterson and Gross 1978: 20: "the extent of our annoyance [at sound levels] depends greatly on ... our previous conditioning, and ... on the character of the noise." The same authors also note (46) that modern quantitative studies of noise tolerance demonstrate a marked variability in peoples' susceptibility to certain types of noise.

${ }^{132}$ I have personally observed that it is possible to speak and be heard in nearly normal conversational tones ( $60 \mathrm{~dB}$; see below, $351, \mathrm{n}$. 138) when only 40 to 50 meters away from a crowd of several hundred protesting students chanting in unison in my direction in the open air setting of 'Temple University's "Quad" in front of the Paley Library (a space smaller than but of roughly the same shape as the Forum, with similarly reverberant stone surfaces surrounding it); 100 meters bebind the same crowd their chanting was hardly noticeable amidst the regular noise of students conversing and traversing the open space.

${ }^{133}$ White 1975: 125.

${ }^{134}$ White 1975: 125. Peterson and Gross (1978: 39) consider a 6 dB drop in noise levels to be significant. 
$\mathrm{s} /$ he needs to hear. ${ }^{135}$ The curved theatron of seats formed by the Gradus Aurelii assisted here, naturally concentrating the attention and hearing of the audience towards the praetor and those speaking before his tribunal, an important factor of which the builder of the Gradus was surely aware. ${ }^{136}$ Finally, the sound generated by speakers on the Rostra (facing toward the tribunals at the Forum's eastern end) would have attenuated fairly rapidly over the 100 meters or so between Rostra and Tribunal due to the Rostra's location in the open air (the divergence effect) and by its passage over the sound-absorbing bodies and clothing of the contional audience, not to mention the backs of those sitting on the Gradus (the dampening effect). ${ }^{137}$ In short, moving the praetor's tribunal 100 meters away from the Rostra, positioning it bebind the mass of contio attendees, and using the Gradus to help focus the audience's attention on the tribunal itself would have offered a significant improvement in working conditions to the praetor and orators speaking at his tribunal.

As for the ambient noise from nearby sources in the eastern end of the Forum, it probably would not have seriously interfered with a praetor's officiating at his tribunal. It is worth noting that many praetorian activities were carried out on a small, even intimate, scale, in which petitioners would approach to within a few feet of the tribunal to speak to the praetor directly. Modern studies demonstrate that even with ambient noise at $50 \mathrm{~dB}$ or so, it is possible for people to speak in normal conversational tones and be completely intelligible to someone 5 meters (16 feet) away. ${ }^{138}$ So, even with the hubbub of the other tribunals/courts in the area, not to mention noisy contiones in the western Forum, we may reasonably expect that a praetor could conduct business in normal or only slightly elevated conversational tones when people approached his tribunal.

Of course deliberate interference with the praetor and his tribunal by tribunes was still possible: Cicero relates that when L. Quinctius, tr. pl. 74, desired to influence the outcome of a trial held against an inimicus, former iudex $\mathrm{C}$. Iunius, he simply marched his entire contional assembly from the Rostra, where he had

${ }^{135}$ White 1972: 125: "To gain ... an improvement in hearing a signal from a discrete direction when several sources are present, the listener must decide which sound he wants to hear and concentrate on it," i.e., give it his attention.

${ }^{136}$ Vitruvius (5.5.7 and 5.8.1-2) discusses the acoustics of theaters, including those whose grandstands are made of wood.

${ }^{137}$ Peterson and Gross 1978: 36.

${ }^{138}$ White $1975:$ 377-378 on "Talker-Listener Distance" required by ambient noise levels. Peterson and Gross (1978: 5-6, 37-38) likewise demonstrate that speech in normal conversational tones $(60 \mathrm{~dB})$ is $100 \%$ intelligible at a distance of 16 feet with background noise of $50 \mathrm{~dB}$. When ambient noise exceeds $60 \mathrm{~dB}$, speakers must either increase their effort or decrease the distance to the listener; 60-75 $\mathrm{dB}$ (heavy factory noise) makes it difficult to communicate without elevating one's voice significantly, $80 \mathrm{~dB}$ and higher makes it impossible to communicate without being within a couple of feet, face to face, and elevating one's voice significantly (as at large cocktail parties in enclosed spaces, the so-called "Cocktail-Party Effect"). But even with background noise of ca $80 \mathrm{~dB}$, one may still be heard from a distance of ca 32 feet if shouting (normally measured at $90 \mathrm{~dB}$; a very soft whisper, by contrast, measures $30 \mathrm{~dB}$ ). 
been railing against Iunius, over to the new tribunal of praetor urbanus C. Verres, where the crowd's menacing presence ensured Iunius' conviction. ${ }^{139}$ This incident highlights an important aspect of functional communications between the western and eastern ends of the Forum after the transfer of the praetor's tribunal: despite the increased distance between it and the tribunes' subsellia, the traditional modes of interaction between these two points appear to have continued as before. This is demonstrated by reports from the years just before and shortly after the tribunal was moved in which we read of people approaching the tribunes' benches to request auxilium from a praetor's judgment; ${ }^{140}$ to request intercession against a praetor's misconduct of a case; ${ }^{141}$ or to argue for the removal of someone's name from the tribunes' annual edict listing people banished from Rome. ${ }^{142}$ Evidently, the long-established ritual of walking from the praetor's tribunal through a public space to the tribunes' subsellia to appeal for assistance continued unabated, despite the movement of one point of contact in that ritual. ${ }^{143}$

There does appear, however, to have been some decrease or impairment of mutual visibility between these two locations. For the previous 110 years during which they kept their "offices" in the Basilica Porcia, tribunes had merely to look out upon or across the Comitium to keep an eye on the praetor and his activities, no more than 50 meters away. With the praetor now situated approximately 150 meters away from the tribunes' benches and at a more oblique viewing angle, the tribunes' line of sight to the praetor's tribunal was obstructed by one or more of the outer columns of the Basilica Porcia. How else are we to explain the otherwise odd tribunician proposal in 74 to remove a column from the basilica? ${ }^{144}$ That an unobstructed view of the praetor's tribunal was regarded as necessary - at least in

${ }^{139}$ Cic. Cluent. 93: accusabat [L. Quinctius] tribunus plebis idem in contionibus, idem ad subsellia; ad iudicium non modo de contione, sed etiam cum ipsa contione veniebat.

${ }^{140}$ Cic. In Tog. Cand. = Asc. 84C; Plut. Caes. 4.1 mistakenly has P. instead of C. Antonius as the accused. C. Antonius Hybrida was prosecuted by Julius Caesar and condemned by praetor inter peregrinos M. Terentius Varro in 76 for having mistreated Greek socii while serving under Sulla. He had only to walk a short distance, less than 50 meters, to the tribunes' benches to ask for their intercession, which he apparently received; cf. Millar 1998: 56-57. Although Antonius appealed to the tribunes before the construction of the Gradus Aurelii, the point is that it was easy and customary, both then and later, for those condemned by a praetor to walk from his tribunal to the tribunes' benches to request auxilium.

${ }^{141}$ Cic. Tull. 7, 38-39: Q. Fabius appealed a practor's decision in 71, but was refused auxilium. Broughton (1951-86: 2.122) thinks the praetor was L. Caecilius Metellus, Verres' successor in Sicily as pro praetore in 70 , hence the date.

${ }^{142}$ Cic. Verr. 2.2.100. In 70, Cicero himself stood apud boc collegium tribunorum plebis ("before this college of tribunes of the plebs") to argue that a man named Sthenius, falsely convicted by Verres, should be removed from the tribunes' annual decree of banishment: the ten tribunes agreed and promptly issued a supplementary decree exempting Sthenius.

${ }^{143}$ Millar (1998: 56-57) points out that "Appeal'... is not a bureaucratic process but a ritual conducted in the open air, consisting in a movement across a public space and an address to the tribuni on their bench."

${ }^{144}$ Plut. Cat. Min. 5.1-2. 
74 - is made evident by one tribune's reaction to a praetor's activities at the new location. Cicero relates the following: after praetor urbanus $\mathrm{C}$. Verres had a citizen brutally flogged at his tribunal, a tribune brought Verres' blood-covered victim to the Rostra, displayed him to the crowd, and then delivered a furious diatribe against the praetor. ${ }^{145}$ That this was not a singular aberration on Verres' part, and that the tribunes had every intention of keeping him in line, seems implicit in their proposal to modify the Basilica Porcia's colonnade so they could have an unobstructed view from their benches to his tribunal. Their proposal came to naught, however: a young M. Porcius Cato (Uticensis) killed it with his first-ever public speech, a passionate plea to leave his ancestor's edifice untouched. ${ }^{146}$

The solution the tribunes eventually implemented to cope with their lineof-sight problem is unknown but may be reasonably inferred from their virtual ubiquity in Rome's civic landscape. When not speaking from the Rostra or deliberating in their offices, tribunes could be found wherever the political or judicial action was, including senate meetings within or outside the pomerium; ${ }^{147}$ electoral or legislative comitia; judicial proceedings; and censuses, to name just a few categories. ${ }^{148}$ Wherever they went, tribunes could also take along their subsellia and set them, for instance, on or before the Rostra for assemblies, as depicted on a coin of $45,{ }^{149}$ or in front of the Carcer to prevent persons going into or coming out of the prison. ${ }^{150}$ Given these facts, it seems probable that the tribunes would have dispatched one of their own, with his bench, to sit near the tribunal whenever the praetor was officiating.

${ }^{145}$ Cic. Verr. 2.1.122: oblitosne igitur bos putatis esse quem ad modum sit iste solitus virgis plebem Romanam concidere? quam rem etiam tribunus plebis in contione egit, cum eum quem iste virgis ceciderat in conspectum populi Romani produxit ("Do you think, therefore, that these onlookers have forgotten how [Verres] would be accustomed to flog until bloody an ordinary Roman citizen? A tribune of the people even brought up the issue in a public assembly when he produced [on the Rostra], before the eyes of the Roman people, a man whom whom [Verres] had had cut to pieces with the rods").

${ }^{146}$ Plutarch places this event (Cat. Min. 5.1-2) between Cato's twentieth birthday in 75 (Cat. Min. 3.5) and his service under L. Gellius Publicola, cos. 72, in the war against Spartacus (Cat. Min. 8.1). Niccolini (1934: 434-435) dates Cato's speech to 75, but the tribunes' obvious need to monitor pr. urb. C. Verres in 74, and the likelihood that the praetor's tribunal was not moved until late in 75 or early in 74 , make the tribunes of 74 the most likely to have made this proposal.

${ }^{147}$ Ryan 1998 thoroughly explores who was present and spoke in senate meetings during the republic.

${ }^{148}$ The virtual ubiquity of tribunes within Rome's civic landscape is one of the main conclusions of Kondratieff (2003: 124-226, especially 221-223).

${ }^{149} \mathrm{M}$. Lollius Palicanus, son of the tribune of 71 who agitated for the restoration of tribunician powers, issued a denarius depicting a tribune's subsellium atop the new Antonian Rostra (later remodeled as the Rostra Augusti), for which see Crawford 1974: 473/1. Morstein-Marx (2004: 53) avers that this coin's combined references to Libertas on the obverse and the Rostra with tribunician subsellium on the reverse "would have evoked all the powerful ideological significance of the tribunician contio for the Roman citizen."

${ }^{150}$ In 60, tribune L. Flavius imprisoned consul Q. Caecilius Metellus Celer and placed his tribunician bench in front of the cell to obstruct those who wished to speak with him; Pompey called him off (Dio 37.50.2-3). 
The continued communications between subsellia and tribunal despite the somewhat impaired mutual visibility, along with the mobility and ubiquity of the tribunes themselves within Rome's civic landscape, leaves very little reason to imagine that the tribunes were somehow physically isolated from the machinery of government by this reapportionment of functional space within the Forum. Indeed, given the tribunes' ability to summon whomever they wished to the Rostra or to their benches ${ }^{151}$-including high-ranking magistrates ${ }^{152}$-it would seem almost impossible to avoid them. As for the praetors presiding over their courts in the eastern end of the Forum, they could now do so with much less interference from tribunician activities on or around the Rostra.

\section{MOVING THE PRAETOR'S TRIBUNAL: SYMBOLIC IMPACT}

How the transfer of the praetor's tribunal might have been read in symbolic terms is difficult to say, given that there is no direct testimony on this topic. Inferred symbolic implications, meanwhile, would necessarily reflect the point of view, optimas or popularis (rhetorically speaking), one wishes to adopt. It may be useful to do just that, to approximate two broad, contrasting, and entirely valid interpretations.

From the point of view of the praetor urbanus, his fellow praetors, and those of a conservative political mindset, this change could have been seen as an enhancement of the praetor's prestige: no longer relegated to a corner of the Comitium where he would suffer interference from tribunician activities, he now had an area of the Forum dedicated to his judicial functions (and those of the quaestiones perpetuae) with a brand new tribunal and seating arrangement for juries. The clustering of the other praetorian tribunals roundabout also would have created a rather imposing judicial presence in the Forum's eastern end. In addition, recall that the onerous task of overseeing the refurbishment of Rome's temples, undertaken by the consuls of 75 , had devolved in the same year on to two praetors, who passed it on to two of their successors in 74, one of whom was praetor urbanus $\mathrm{C}$. Verres. His repairs to the Temple of Castor at the same time that his tribunal was relocated nearby may have signified to some that praetors were now "taking charge" of this important, highly symbolic monumental area. ${ }^{153}$

${ }^{151}$ Kondratieff (2003: 588) has eight examples of tribunician summonses issued between 187 and 58 and twenty-three examples of arrests or attempted arrests by tribunes or their viatores between 212 and 44 (526). The locus classicus for the tribunes' ability to summon people is Gellius 13.12.4-9, esp. 13.12.6; see also Mommsen 1887: 2.313, n. 2; Botsford 1909: 148; Pina Polo 1996: 48; Morstein-Marx 2004: 171, n. 53.

${ }^{152}$ In 76 , with the tribunate at its nadir of power and prestige, $\mathrm{Cn}$. Sicinius produced both consuls on the Rostra: Cic. Brut. 217: [Cn. Sicinius] cum tribunus plebis Curionem et Octavium consules produxisset. .. ; cf. Sall. Hist. 2.23-26M, 3.48.8-10M; ps.-Asc. 189 Stangl; Millar 1998: 60. In 66, praetor M. Cicero was summoned to appear before the people by some anonymous tribunes: Dio

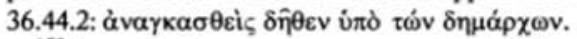

${ }^{153}$ I owe this idea to a private communication from $B$. Frier. For the Temple of Castor's significance as a "witness" of all that is done in the Forum, including overseeing the laws, the courts, the highest 
Optimates would surely choose to characterize this new situation as reflecting the increased importance and prestige of the praetors and their courts. That they saw it as leaving the tribunes languishing in physical or symbolic isolation, however, seems far less probable given the ubiquity of the tribunes themselves. Besides, such a view would logically require them to include in the "isolated" category everything else in the western Forum: the quaestors and the Aerarium (state treasury) where they worked; the Carcer and Tarpeian rock; Sulla's new Tabularium and the basilicas and temple on the Capitol's east face; even the new Curia Cornelia and the old Rostra, where stood the gilt equestrian statue of Sulla himself.

The tribunes, other popularis politicians, and their supporters might have viewed the removal of the praetor's tribunal as openly acknowledging the return of dignitas to the tribunate, and as clearing the way for the tribunes' revitalized contional habit. In other words, they could have chosen to believe that the praetors had been forced to give way to the tribunes, who now held full sway over the Forum's western end and over the Rostra itself, Rome's most honored and conspicuous location for commemoration and for oratory. ${ }^{154}$ Surrounded by the venerable buildings and sites of the western Forum, the tribunes could be seen as remaining firmly nestled within the symbolic heart of Roman power and popular sovereignty, of which they were an integral part. Lending some weight to this point of view is the fact that the Romans never regarded the praetor's tribunal as the Forum's political and symbolic center: that honor went to the Curia and Comitium, as proved by the continued use, well into the second century c.e., of the formula in comitio in curia. ${ }^{155}$

counsels, etc., see Cic. Verr. 2.5.186: vosque, omnium rerum forensium, consiliorum maximorum, legum iudicionumque arbitri et testes celeberrimo in loco populi Romani locati, Castor et Pollux ("And you, Castor Pollux, situated in the most renowned location belonging to the Roman people, judges and witnesses of all our forum activities, of our most important deliberations, of our laws and lawcourts"). Nielsen (1992: 46-60) has a complete set of references for the temple's symbolic importance.

${ }^{154}$ Pliny ( $\left.N H 34.24\right)$ notes that in the 160 s the senate ordered that, on account of his being killed while on embassy to Syria, "a statue of $\mathrm{Cn}$. Octavius be erected in the most conspicuous place, and that statue stands on the Rostra": senatus statuam poni iussit quam oculatissimo loco, eaque est in rostris. In two passages postdating the relocation of the praetor's tribunal, Cicero (Deiot. 34) points out that "there is no more brilliant location for a statue than on the Rostra" (nullus locus est ad statuam quidem rostris clarior) and proclaims ( $\mathrm{Log} . \mathrm{Man} .1$ ) that "this place [the Rostra] has ever seemed to me the most ample for taking action, the most magnificent for speaking" (mibi semper ... bic autem locus ad agendum amplissimus, ad dicendum ornatissimus est visus). Morstein-Marx (2004: 50-54) provides an acutely observed commentary on these passages, demonstrating not only that the Rostra was indeed the focal point of the Forum, but also that it was "virtually metonymic for deliberation and decision by the Roman People." On 54-55 he also argues that the Rostra's role as the "point of intersection between Senate and People" was symbolically strengthened by the close proximity of the Curia and the Temple of Concordia.

${ }^{155}$ Richardson 1992: 98 s.v. "Comitium"; Platner and Ashby (1929: 144 s.v. "Curia Julia") cite the Hadrianic SC de Nundinis saltus Beguensis (138 c.e.) in Ephemeris Epigrapbica II (1874) 273, 282 = CIL VIII 00270. 
In this paper, I have attempted to situate a significant change in the Forum's civic topography within a broad historical framework in order to offer an explanation for when and why that change was made. The outward expansion of tribunician activity, and its potential for interference with the activities of the praetor at his tribunal, made the move a practical necessity. This move was apparently delayed by historical contingencies, including the virtual suppression of tribunician activity just as praetorian activity in the Forum was increased considerably due to the establishment of multiple permanent courts. Finally, the move seems to have been implemented only when a political expedient-the restoration of dignitas to the tribunate by a consul seeking popular favor-led to the revival of tribunician contiones and the reemergence of the potential for mutual interference between tribunes and praetors. In this light, removing the praetor and his tribunal from the traditional contional area to the Forum's eastern end seems to have been a practical solution to the very real problem of overlapping and conflicting spheres of activity. Once implemented, the tribunes apparently had a wider area in which to carry out their newly revived contional activities, while the praetors could operate with less tribunician interference in an area dedicated mostly, if not solely, to their judicial activities. How this modification to the Forum's civic topography was viewed in symbolic terms depends, ultimately, on the point of view one chooses to adopt. While the answer to this particular question could have as many nuances and variations as there are minds to consider it, it is easy enough to offer some broad symbolic interpretations favoring either praetors or tribunes. To better understand the purpose - and, perhaps, the symbolic meaning - inherent in the reorganization of public space, and the effect it may have had on the people or institutions that functioned within that space, we must move beyond mapping topographical changes on to preconceived notions or established theories. A consideration of all the available evidence, synchronic and diachronic, for human activity connected to various points in that landscape brings with it both an improved understanding of the historical conditions and antecedents that may have led to such changes, and a closer approximation of how the city's inhabitants might have interpreted them. Along the way, we might also arrive at a more comprehensive and nuanced understanding of how the Roman people, their magistrates, and their officers functioned individually and collectively within their evolving civic landscape.

Greek and Roman Classics

Temple University

1114 W. Berks St., 350 Anderson Hall

Philadelphia, PA 19122

U.S.A.

ekondrat@temple.edu 


\section{BIBLIOGRAPHY}

Aldrete, G. S. 1999. Gestures and Acclamations in Ancient Rome. Baltimore and London. Ammerman, A. J. 1990. "On the Origins of the Forum Romanum," AJA 94: 627-645. Badian, E. 1984. "The Death of Saturninus: Studies in Chronology and Prosopography," Cbiron 14: 101-147.

- 1996. "Tribuni Plebis and Res Publica" in J. Linderski (ed.), Imperium sine fine: T. Robert S. Broughton and the Roman Republic. Stuttgart. 187-213.

Brennan, T. C. 2000. The Praetorship in the Roman Republic. Oxford.

Broughton, T. R. S. 1951-86. The Magistrates of the Roman Republic. 3 vols. New York. Carafa, P. 1998. Il comizio di Roma dalle origini all'età di Augusto. Bull. della Comm. Arch. Com. di Roma Suppl. 5. Rome.

Castagnoli, F. 1964. "Note sulla topografia del Palatino e del Foro Romano," ArchCl 16: 173-199.

Chiofi, L. 1999. "Puteal Libonis / Scribonianum," in Steinby 1993-99: 4.171-173.

Coarelli, F. 1992. Il Foro Romano II: Periodo Repubblicano e Augusteo ${ }^{2}$. Rome.

— 1993a. "Carcer," in Steinby 1993-99: 1.236-237.

- 1993b. “Comitium," in Steinby 1993-99: 1.308-314.

— 1999. "Rostra (età repubblicana)," in Steinby 1993-99: 4.212-213.

Corbeill, A. 1996. Controlling Laughter: Political Humor in the Late Roman Republic. Princeton.

- 2002. "Political Movement: Walking and Ideology in Republican Rome," in D. Fredrick (ed.), The Roman Gaze. Baltimore. 182-215.

Crawford, M. H. 1974. Roman Republican Coinage. Cambridge.

David, J. M. 1980. "Eloquentia popularis et conduites symboliques des orateurs de la fin de la République: problèmes d'efficacité," QS 12: 171-211.

- 1983. "Les orateurs des municipes à Rome: intégration, réticences et snobismes," in Les "bourgeoisies" municipales italiennes aux If" et $r^{\prime \prime}$ siecles av, J.-C. Paris and Naples. 309-323.

-1992. Le patronat judicaire au dernière de la République romaine. Rome.

-1995. "Le tribunal du préteur: contraints symboliques et politiques sous la République et le début de l'Empire," Klio 77: 371-385.

- 2006. "Rhetoric and Public Life," in N. Rosenstein and R. Morstein-Marx (eds.), A Companion to the Roman Republic. Oxford. 421-438.

David, J. M. and M. Dondin. 1980. "Dion Cassius, XXXVI, 41, 1-2: Conduites symboliques et comportements exemplaires de Lucullus, Acilius Glabrio et Papirius Carbo (78 et 67 a.C.)," MEFRA 92: 199-213.

Epstein, D. F. 1983. “Inimicitia between M. Octavius and Ti. Gracchus tribuni plebis, 133 в.c.," Hermes 111: 296-300.

Farrell, J. 1986. "The Distinction between comitia and concilium," Athenaeum 74: 408-438. Favro, D. 1999. "The City is a Living Thing: The Performative Role of an Urban Site in Ancient Rome," in B. Bergmann and C. Kondoleon (eds.), The Art of Ancient Spectacle. New Haven and London. 205-220.

1996. The Urban Image of Augustan Rome. Cambridge.

Flower, H. 1996. Ancestor Masks and Aristocratic Power in Roman Culture. Oxford.

Frier, B. 1983. “Urban Praetors and Rural Violence: The Legal Background of Cicero's

Pro Caecina," TAPA 113: 221-241. 
-1985. The Rise of the Roman Jurists. Princeton.

Giuliani, C. F. 1995. "Forum Romanum (Lastricati)," in Steinby 1993-99: 2.343-345.

Hill, P. V. 1989. The Monuments of Ancient Rome as Coin Types. London.

Hölkeskamp, K.-J. 1993. "Conquest, Competition and Consensus: Roman Expansion in Italy and the Rise of the Nobilitas," Historia 42: 12-39.

- 2000. "The Roman Republic: Government of the People, by the People, for the People?" Review of Millar 1998 in SCI 19: 203-223.

Hollstein, H. 1993. Die stadtrömische Münzprägung der Jabre 78-50 v. Chr. zwischen politischer Aktualitāt und Familienthematik. Kommentar und Bibliographie. Munich.

Hölscher, T. 1978. "Die Anfänge römischer Repräsentationskunst," RM 85: 315-357.

Hug, A. 1932. "Subsellium," RE 4A: 502.

Jordan, H. 1871. Topographie der Stadt Rom in Altertum 1.1. Berlin.

Kondratieff, E. 2003. Popular Power in Action: Tribunes of the Plebs in the Later Republic. Diss., Philadelphia.

- 2004. "The Column and Coinage of C. Duilius: Innovations in Iconography in Large and Small Media in the Middle Republic," SCI 23: 1-39.

- forthcoming. "The Urban Praetor's Tribunal in the Roman Republic," in W. V. Harris and F. de Angelis (eds.), Spaces of Justice in the Roman World: Columbia Studies in the Classical Tradition. Leiden.

Konrad, C. F. 1994. Plutarch's Sertorius. A Historical Commentary. Chapel Hill.

Korhonen, K. 1999. “Tribunal Aurelium, Gradus Aurelii," in Steinby 1993-99: 5.86-87.

Krause, C. 1976. "Zur bauliche Gestalt des republikanischen Comitiums," MDAI(R) 83: 31-69.

Kunkel, W. and R. Witman. 1995. Staatsordnung und Staatspraxis der römischen Republik 2: Die Magistratur. Munich.

Lintott, A. W. 1999a. The Constitution of the Roman Republic. Oxford.

1999b. Violence in Republican Rome ${ }^{2}$. Oxford.

MacMullen, R. 1980. “How Many Romans Voted?," Athenaeum 58: 454-457.

Marshall, B. A. 1985. A Historical Commentary on Asconius. Columbia, Missouri.

Millar, F. 1984. "The Political Character of the Classical Roman Republic, 200-151 в.c.," JRS 74: 1-19.

1986. "Politics, Persuasion and the People before the Social War, 150-90 в.c.," JRS 76: 1-10.

- 1989. "Political Power in Mid-Republican Rome: Curia or Comitium?," JRS 79: 138-150.

— 1995a. "The Last Century of the Republic: Whose History?," JRS 85: 239-247.

- 1995b. "Popular Politics at Rome in the Late Republic," in I. Malkin and W. Z.

Rubinsohn (eds.), Leaders and Masses in the Roman World: Studies in Honor of Zvi Yavetz. Leiden. 91-113.

1998. The Crowd in Rome in the Late Republic. Ann Arbor.

- 2002. The Roman Republic and the Augustan Revolution. Chapel Hill.

Morstein-Marx, R. 2004. Mass Oratory and Political Power in the Late Roman Republic. Cambridge.

Mouritsen, H. 2001. Plebs and Politics in the Late Roman Republic. Cambridge.

Murray, W. M. and P. M. Petsas. 1989. Octavian's Campsite Memorial for the Actian War. TAPS 79.4. Philadelphia. 
Nash, E. 1968. Pictorial Dictionary of Ancient Rome ${ }^{2}$. London.

Niccolini, G. 1932. Il tribunato della plebe. Milan.

1934. I fasti dei tribuni della plebe. Milan.

Nicolet, C. 1980. The World of the Citizen in Republican Rome. Berkeley and Los Angeles.

Nielsen, I. and B. Poulsen (eds.). 1992. The Temple of Castor and Pollux 1. Luca.

Noreña, C. 2002a. "Castor, Aedes," in L. Haselberger and D. G. Romano (eds.), Mapping Augustan Rome, Portsmouth. 83-84.

- 2002b. "Puteal Libonis / Scribonianum," in L. Haselberger and D. G. Romano (eds.), Mapping Augustan Rome, Portsmouth. 211-212.

Paananen, U. 1993. "Legislation in the comitia centuriata," in Paananen et al. 1993: 9-73.

Paananen, U., K. Heikkilä, K. Sandberg, L. Savunen and J. Vaahtera (eds.). 1993. Senatus

Populusque Romanus: Studies in Roman Republican Legislation. Helsinki.

Papi, E. 1999a. “Tabernae Argentariae," in Steinby 1993-99: 4.10-12.

- 1999b. "Tabernae circa Forum," in Steinby 1993-99: 4.12-13.

Patterson, J. R. 1992. "Survey Article: The City of Rome: from Republic to Empire," JRS 82: 186-215.

- 2006. "The City of Rome," in N. Rosenstein and R. Morstein-Marx (eds.), A Companion to the Roman Republic. Oxford. 354-364.

Peterson, A. G. P. and E. E. Gross. 1978. Handbook of Noise Measurement. Concord.

Pietilä-Castren, L. 1987. Magnificentia Publica: The Victory Monuments of the Roman Generals in the Era of the Punic Wars. Helsinki.

Pina Polo, F. 1989. Las Contiones civiles y militares en Roma. Saragossa.

- 1995. "Procedures and Functions of Civil and Military Contiones in Rome," Klio 77: 203-216.

Platner, S. and T. Ashby. 1929. Topographical Dictionary of Ancient Rome. Oxford.

Purcell, N. 1989. "Rediscovering the Roman Forum," JRA 2: 156-166.

- 1995. "The Forum Romanum (The Republican Period)," in Steinby 1993-99: 2.325-336.

Richardson, L. Jr. 1992. A New Topographical Dictionary of Ancient Rome. Baltimore.

Ryan, F. X. 1998. Rank and Participation in the Republican Senate. Stuttgart.

Sandberg, K. 1993. "The Concilium Plebis as a Legislative Body during the Republic," in Paananen it et al. 1993: 74-96.

- 2001. Magistrates and Assemblies: A Study of Legislative Practices in Republican Rome. Rome.

Scheid, J. 1975. “Scribonia Caesaris et les Julio-Claudiens," MEFRA 87: 349-375.

Seager, R. 1994. "The Rise of Pompey: Part II. Politics at Rome, 77-71 в.c.," in The Cambridge Ancient History IX $^{2}$. Ed. J. A. Crook, A. Lintott, E. Rawson. Cambridge. 210-215.

Sehlmeyer, M. 1999. Stadtrömische Ebrenstatuen der republikanischen Zeit. Stuttgart.

Stambaugh, J. 1988. The Ancient Roman City. Baltimore.

Steinby, E. M. ed. 1993-99. Lexicon Topographicum Urbis Romae. 5 vols. Rome.

Sumi, G. S. 1997. "Power and Ritual: The Crowd at Clodius' Funeral," Historia 46: 80-102.

Sumner, G. V. 1973. The Orators in Cicero's Brutus: Prosopography and Chronology. Toronto. Sutherland, C. H. V. 1984. The Roman Imperial Coinage 1: From 31 B.C. to A.D. 69. London. 
Taylor, L. R. 1963. “Was Tiberius Gracchus' Last Assembly Electoral or Legislative?,” Athenaeum 41: 51-69.

- 1966a. Roman Voting Assemblies. Ann Arbor.

- 1966b. "Appian and Plutarch on Tiberius Gracchus' Last Assembly," Athenaeum 44: 238-250.

Thommen, L. 1989. Das Volkstribunat der spāten römischen Republik (133-43 в.C.E). Stuttgart.

- 1995. "Les lieux de la plèbe et de ses tribuns dans la Rome républicaine," Klio 77: 358-370.

Vaahtera, J. 1993. "On the Religious Nature of the Place of Assembly," in Paananen et al. 1993: 97-116.

Vanderbroeck, P. J. J. 1987. Popular Leadership and Collective Behavior in the Late Roman Republic (ca. 80-50 B.C). Amsterdam.

Welch, K. 2007. The Roman Amphitheatre. Cambridge.

White, F. A. 1975. Our Acoustic Environment. New York.

Williams, J. 2001. "Moneta and the Monuments: Coinage and Politics in Republican Rome," JRS 91: 27-49.

Wiseman, T. P. 1999. “Saxum Tarpeium," in Steinby 1993-99: 4.237-238.

Ziolkowski, A. 1992. The Temples of Mid-Republican Rome and Their Historical and Topograpbical Context. Rome. 


\section{READING ROME'S EVOLVING CIVIC LANDSCAPE IN CONTEXT}

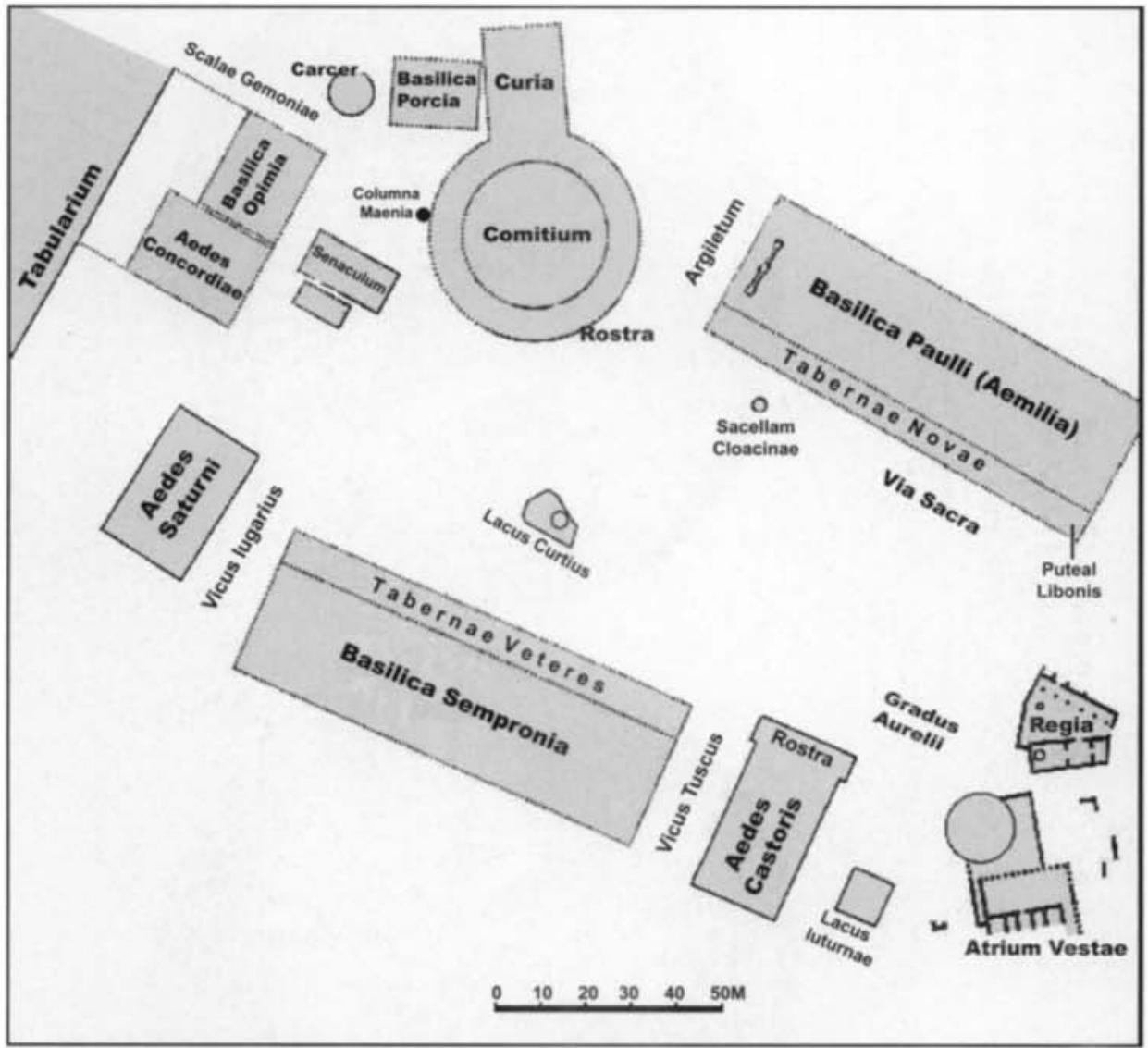

Map 1. Plan of the Forum after 75 B.c.e. Adapted from J.-M. David and H. Broise, Architecture et sociêté de larchaissme gree à la fin de la république romaine: actes du Colloque international, Centre national de la recherche scientifique (France) (École française de Rome, 1983) 244. Note that the Comitium should probably be depicted as square. The location of the Gradus Aurelii is approximate, as is the location of the Puteal Libonis (or Puteal Scribonianum). 
PHOENIX
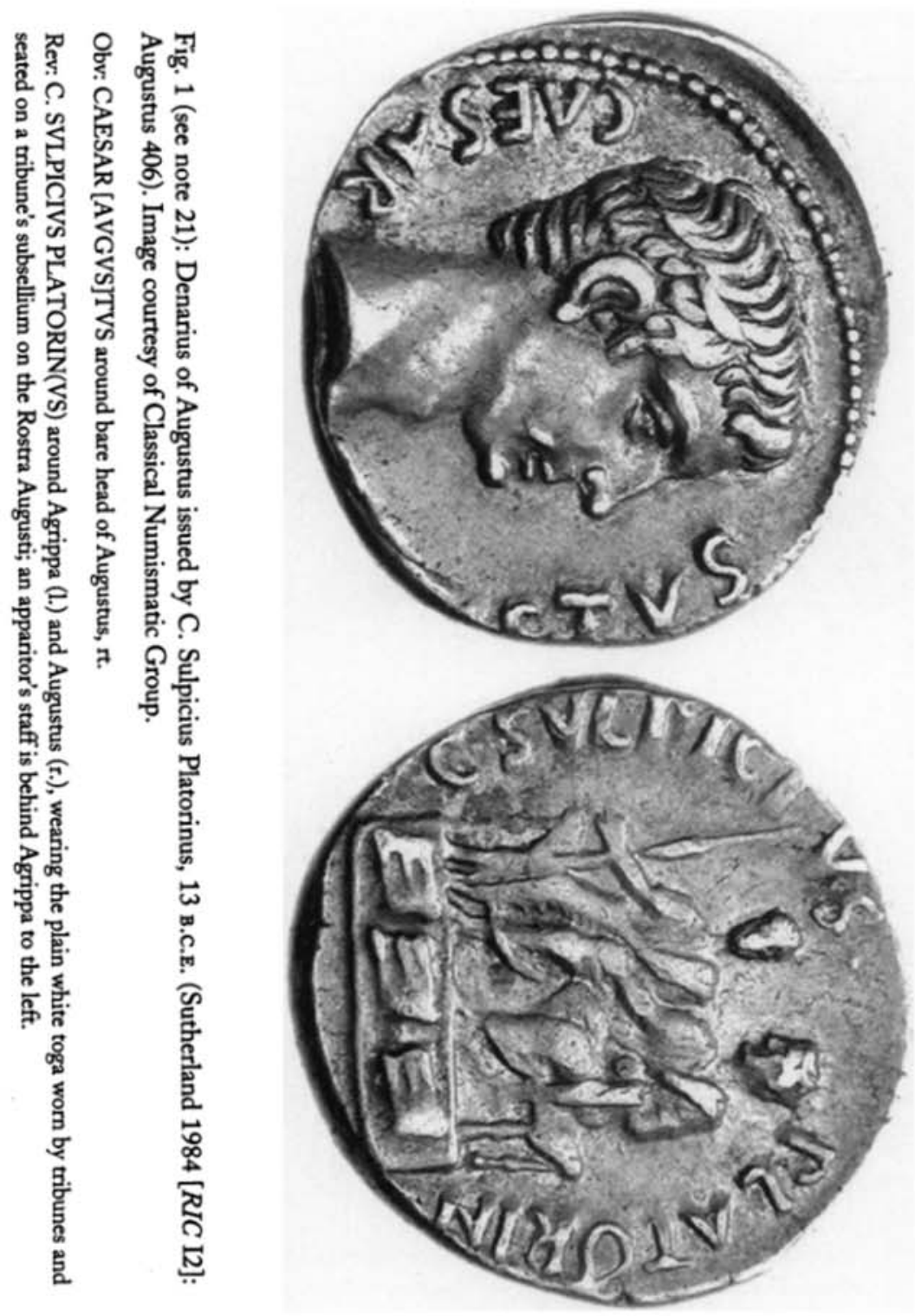
READING ROME'S EVOLVING CIVIC LANDSCAPE IN CONTEXT
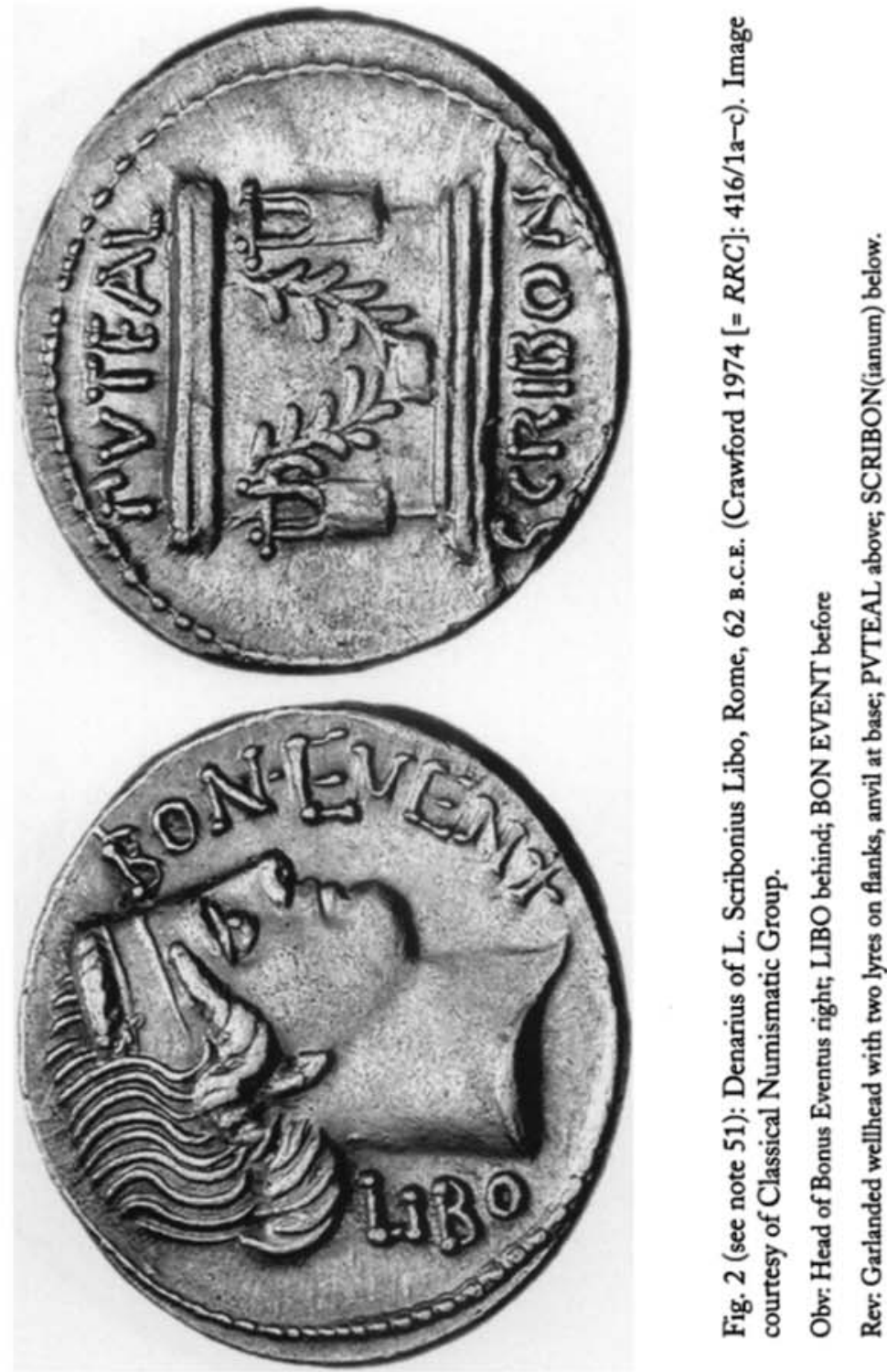
PHOENIX
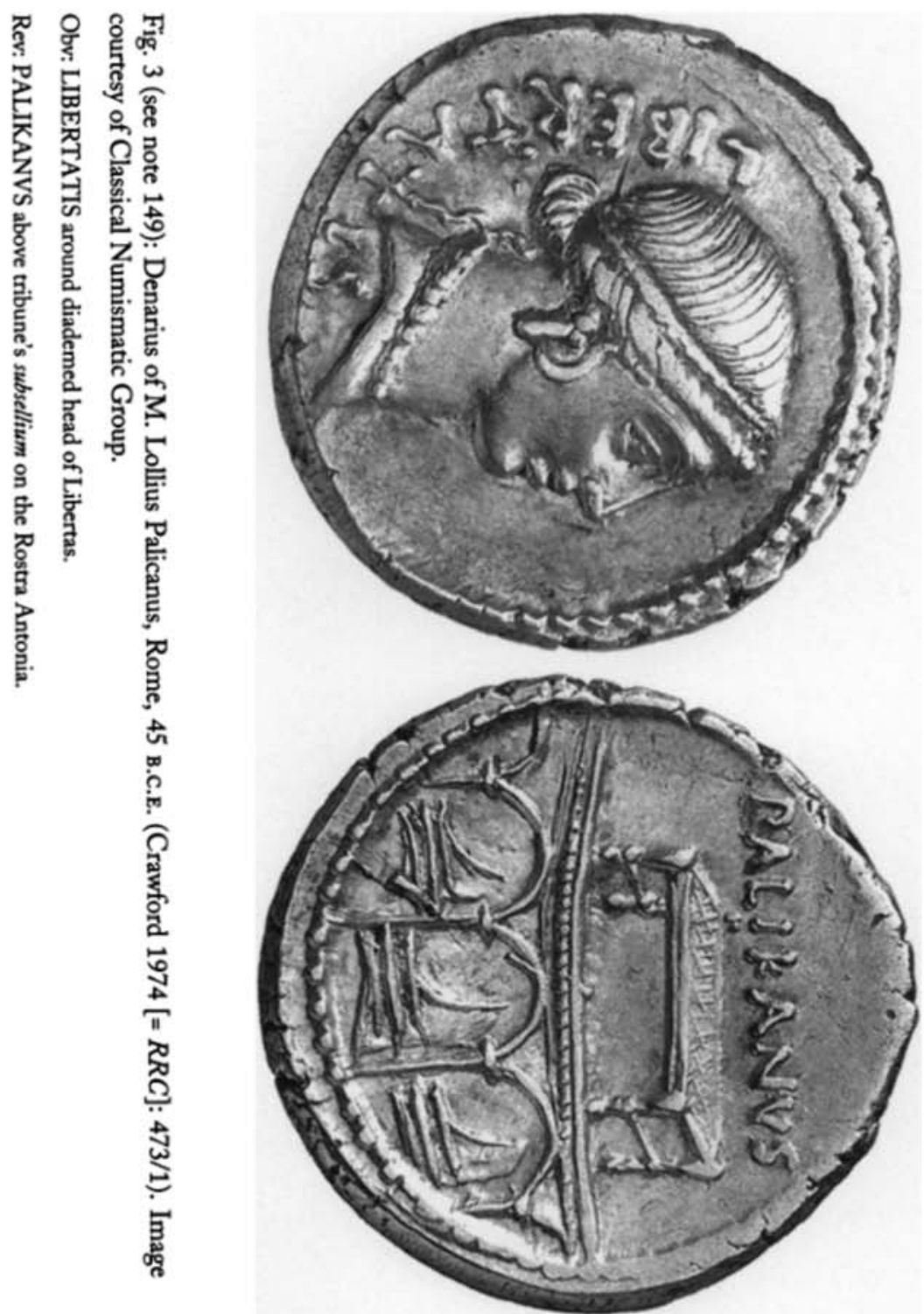